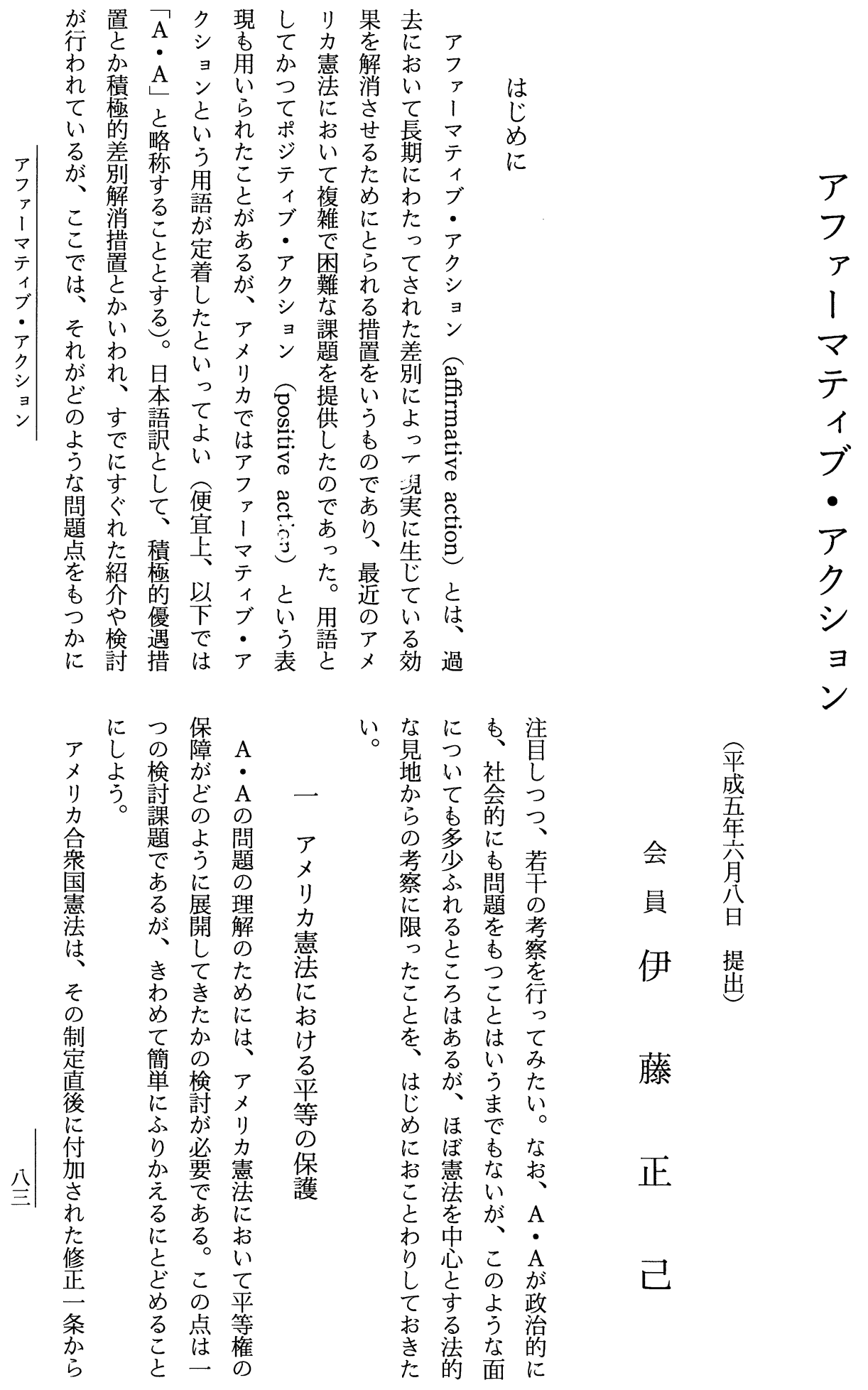




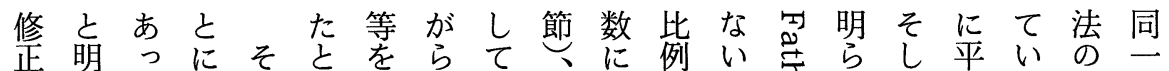
步言た よ

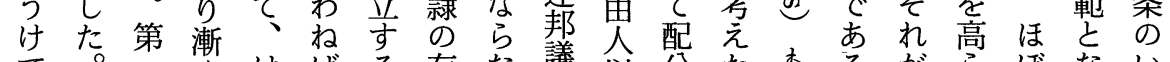

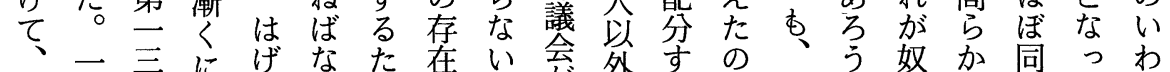



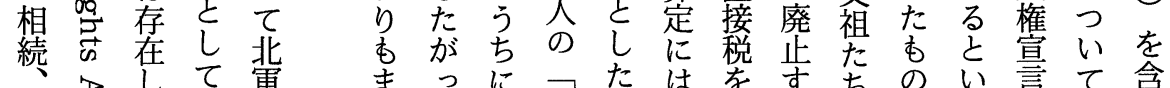

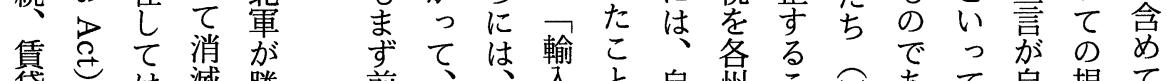

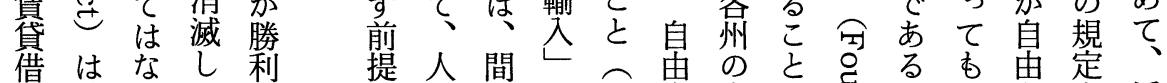

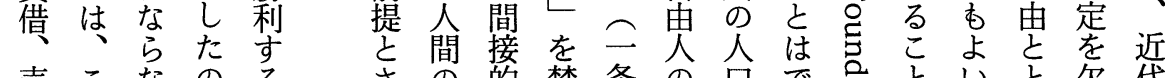



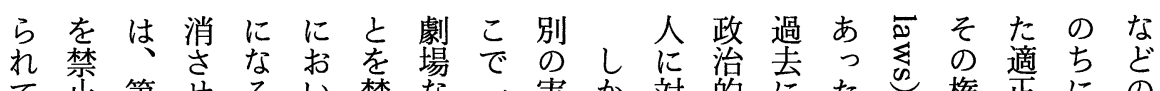
て歨第せる。禁な二寒加対的にた氙権正にの い守二る。て正よ゙八態し守な奴。限な黒平

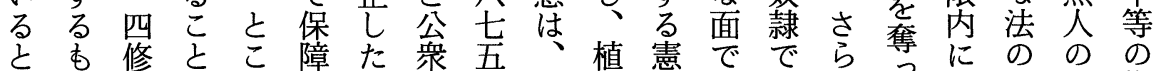

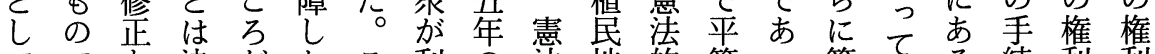
てで市決がたこ利の法地的等っ第はる続利利 ああ、し、古市的時平をた云な者保を

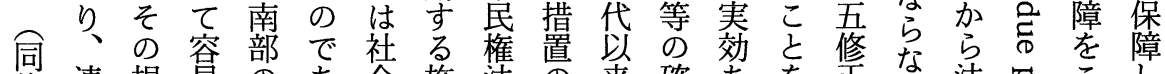



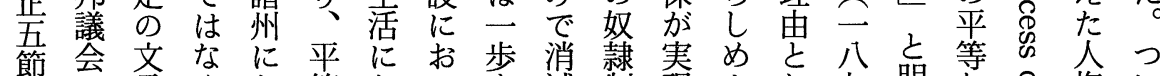

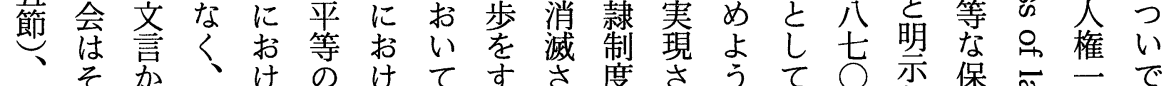

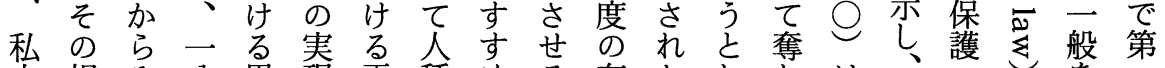

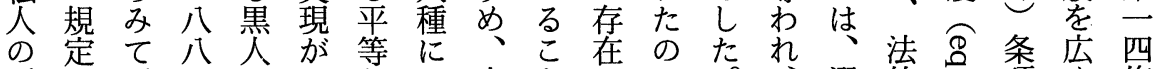

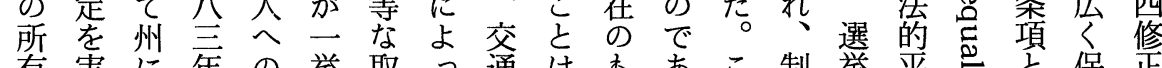

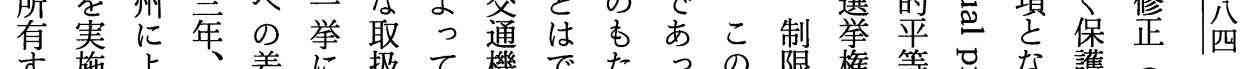

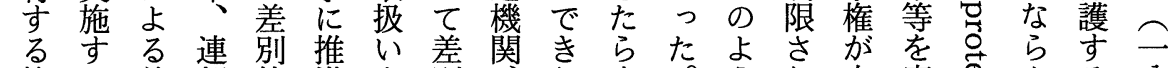
施る差邦的進を別な娄。う㣗人宣怘んる八 設権別最なさ私がレか社にな種奛芯で瞡六

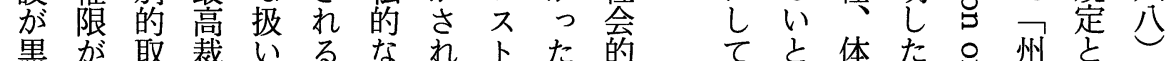

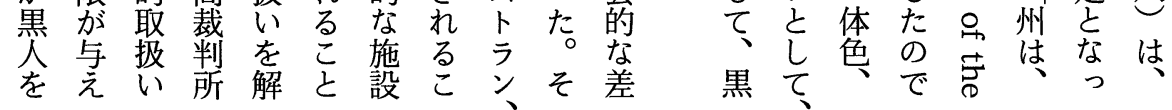




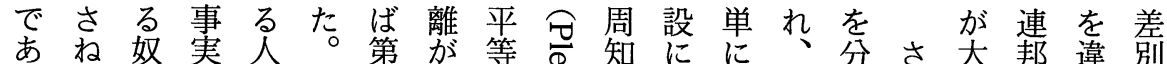

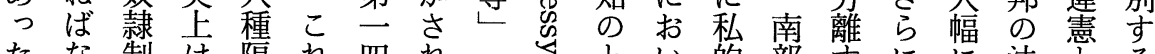

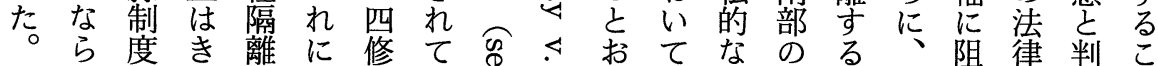

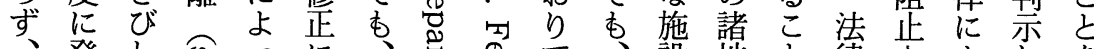



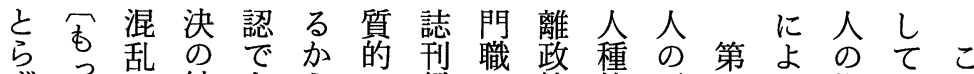
ずるを結きら、行 の策的平云っ 権確の

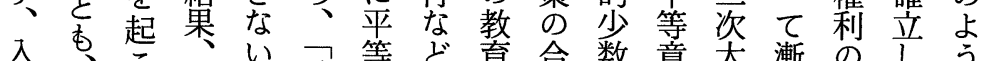

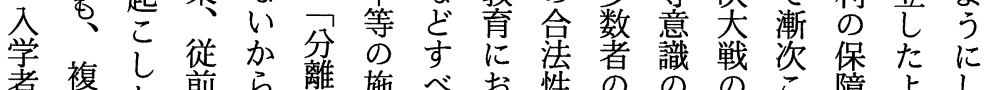

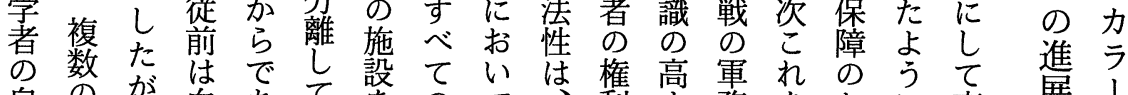



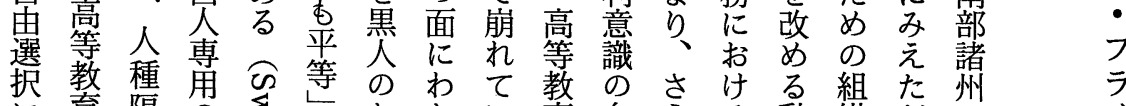

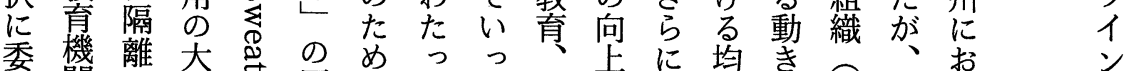

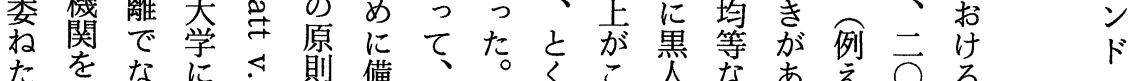

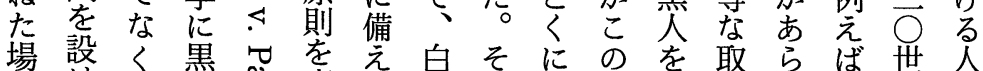

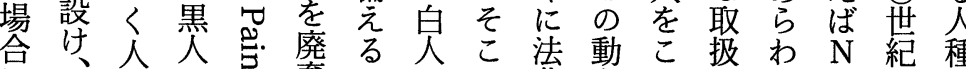

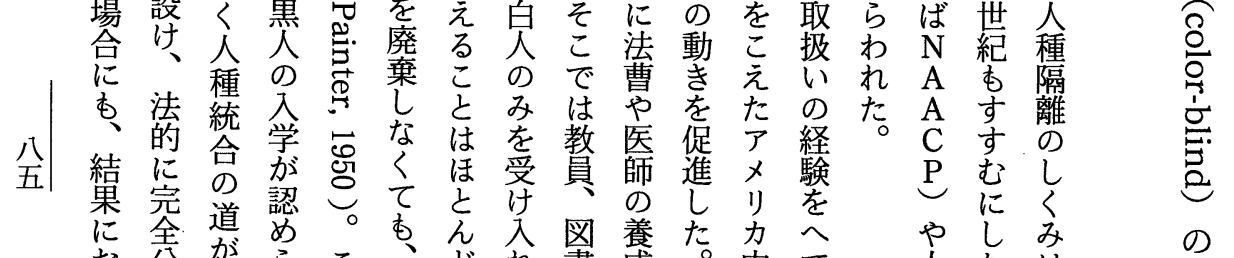

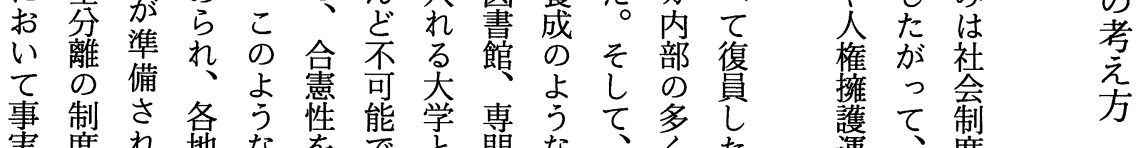
実度れ地な判容あ実雑専隔の黒㷲黒芫 
裁学明とれのなお良多るメ四包古判で学别

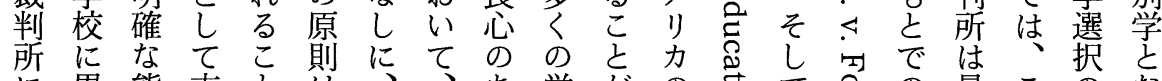

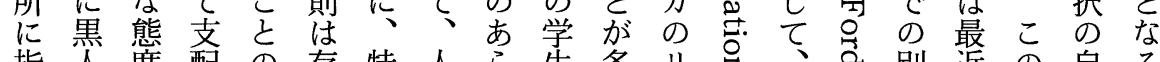
指人度配の存特人弓生多り引 怘別近の自る

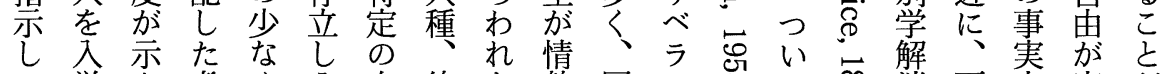

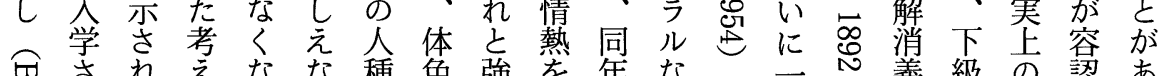

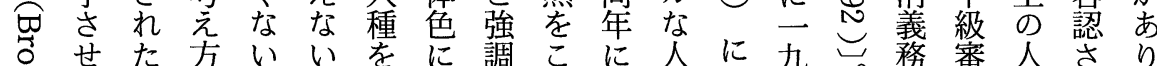

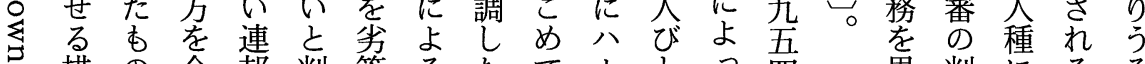

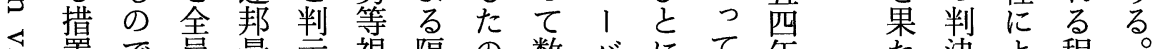

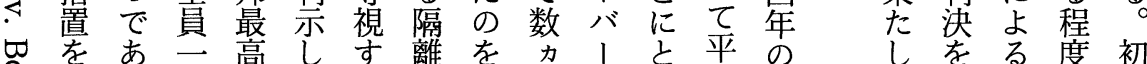

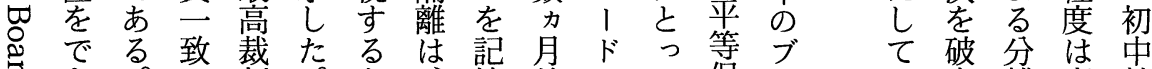

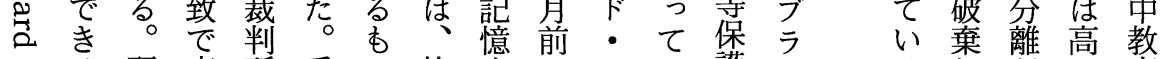
○る翌変所重の施尌にロに護ウ

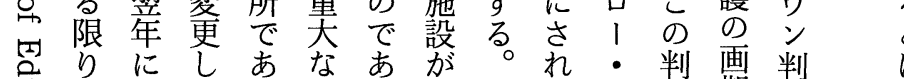
○にしあなあが。れ ・判画判はそ等市異

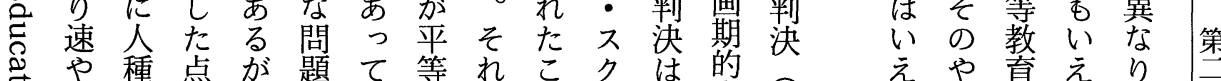

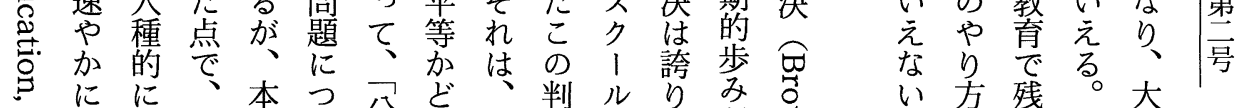

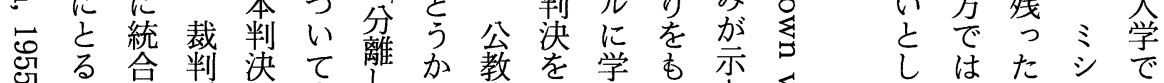

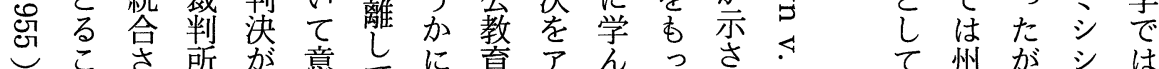

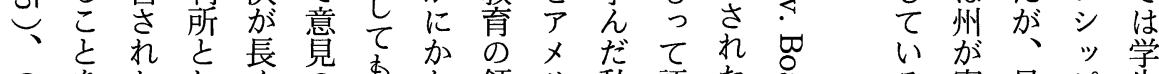

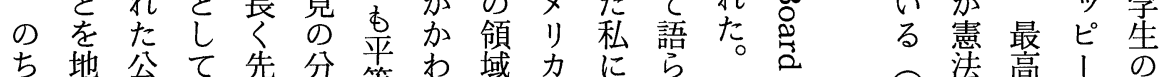

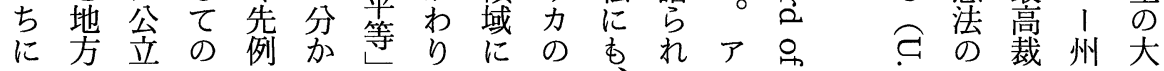


動莧な政め㗢満識底のよい切。害入筧童う萑

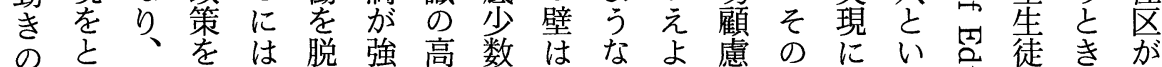

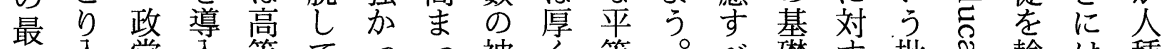

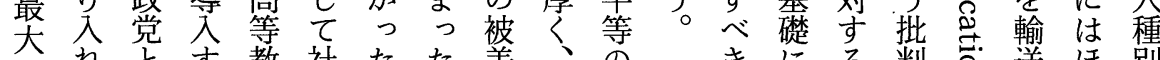

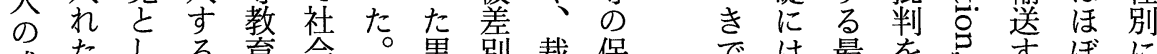

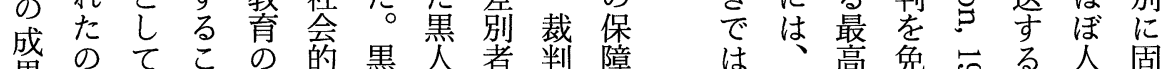

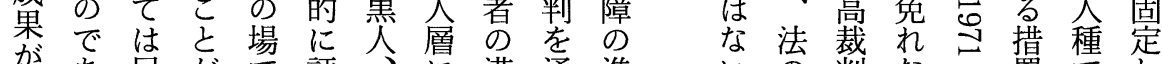

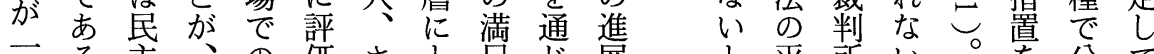

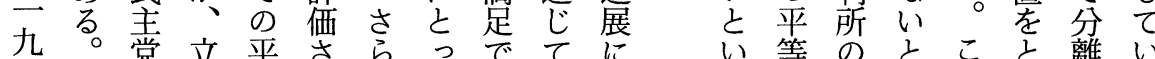

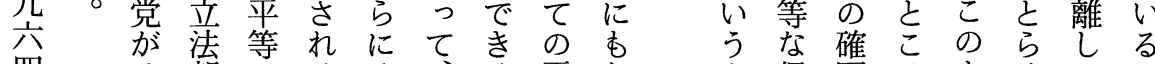

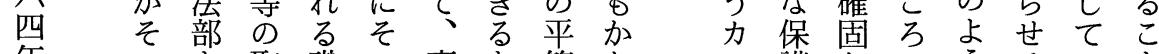
年のと取職の高す等汃ラ護たでうるいる

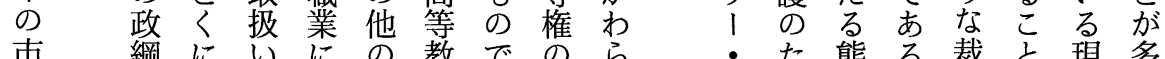

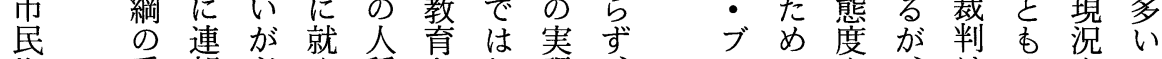
権重邦必く種とな現、ラに觉住みをの

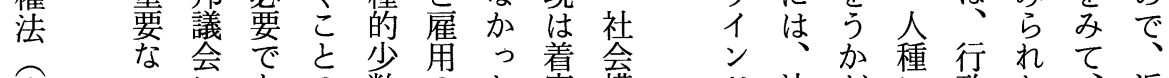

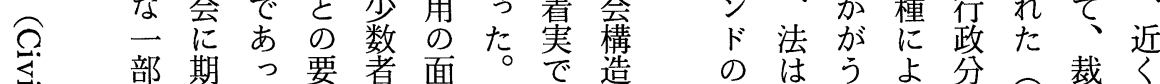

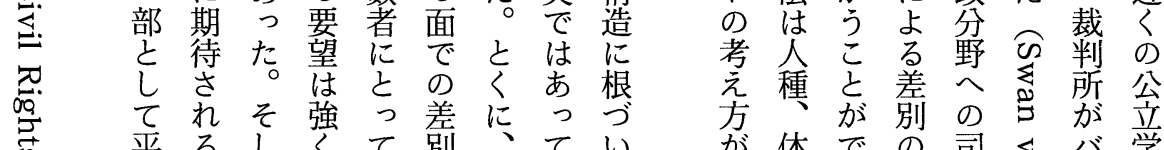

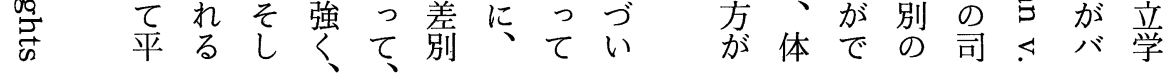






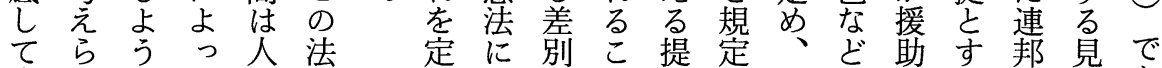
実れとて間律少は禁案しこを娄る法地あ 現るし差とは、る男歨を隹たの理るすでにる。



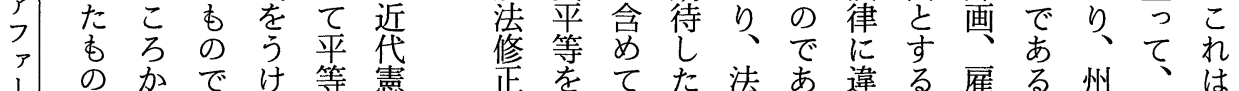

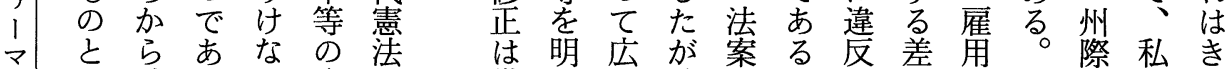

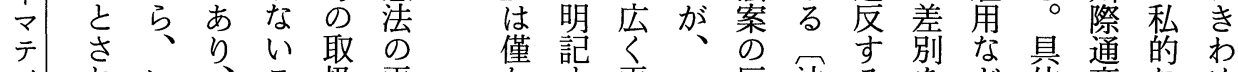
ブ热いわア 子そ る

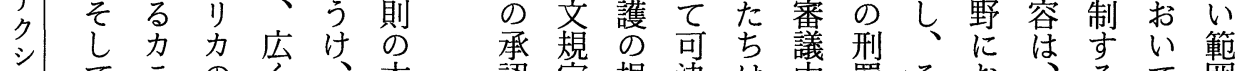

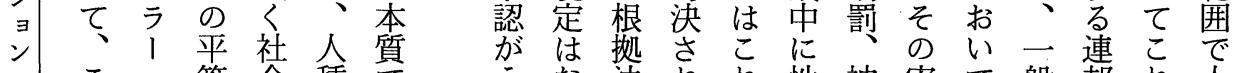

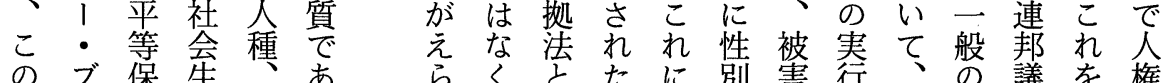

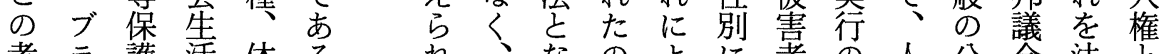

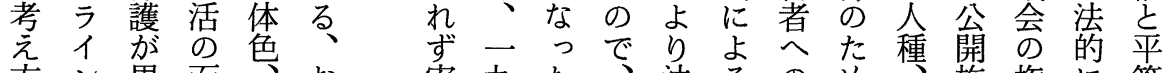
方ン黒面出打実九だ法るのめ種型権に等

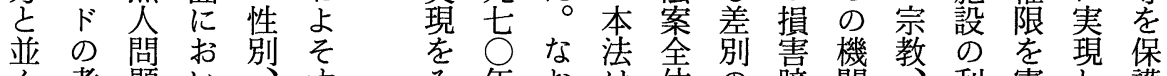
ん考題い守

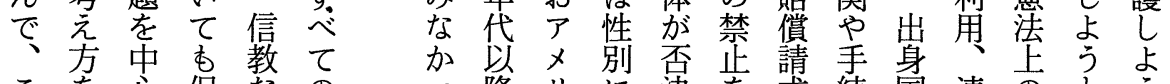
こを心保なのっ降りに決を求続国連のとう

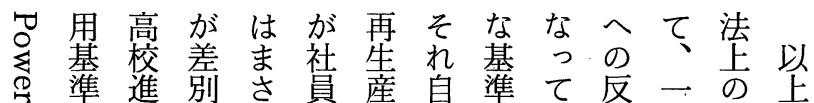
○学的に貝産臬準永省部平尗

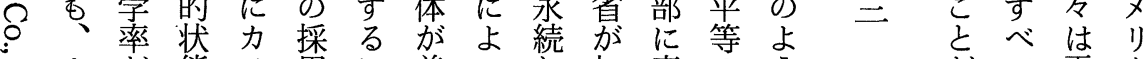

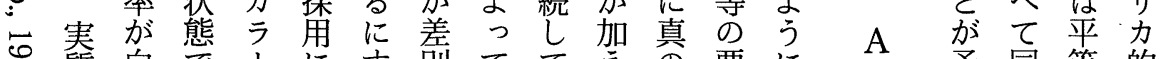

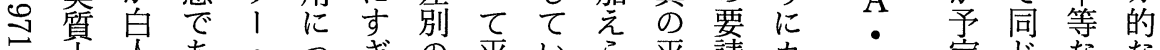

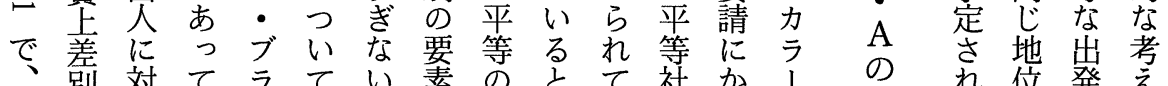

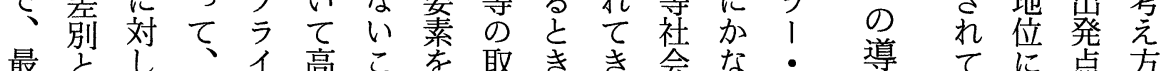

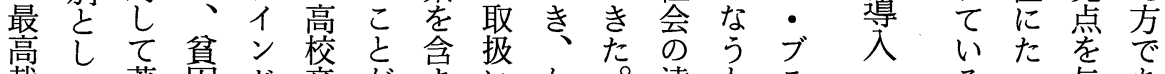
裁て著困ド卒がまいか。達すラ は働しそでと判ながり過成の的とてえる そくくのはい明いさに去にでン い自ら自

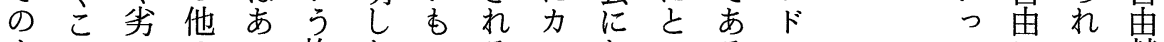

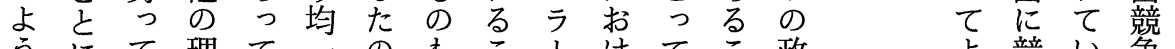

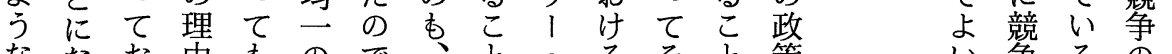
ななお审ので、と、るそと策 基ろれに、基あ塞にブ差れがが 八集う隹よ高集る。祭な今別が認す 市宗形あ教た例去でン 事分方

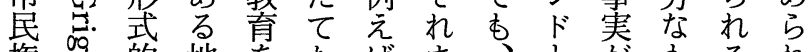

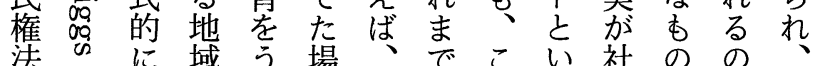

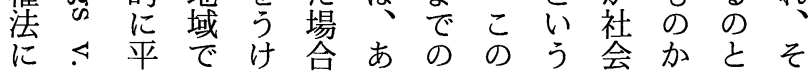

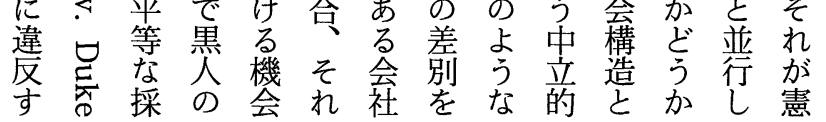
い争るの あ゙し の だ う寊ある う占学京 道 占充 き れ 拓少す 


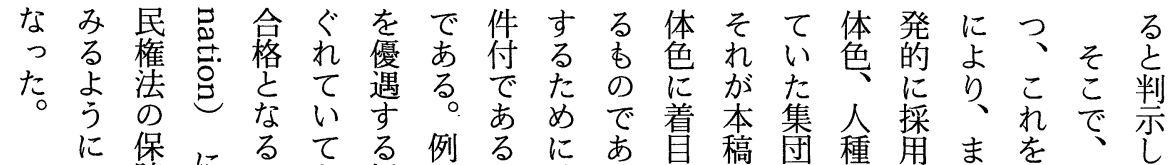

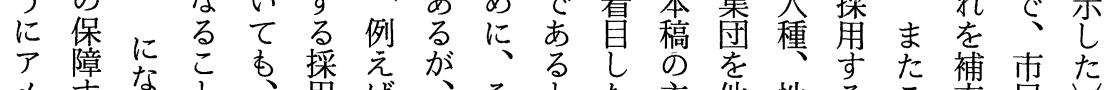

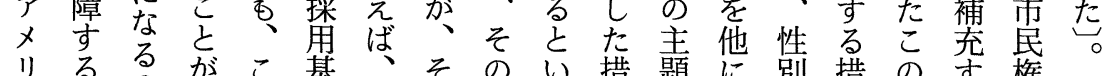

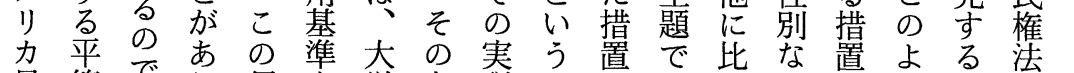

最等でり優を学存䚆こ真であ比な置よ厼法

高権 あ、遇たの在さ等をるてによな統の

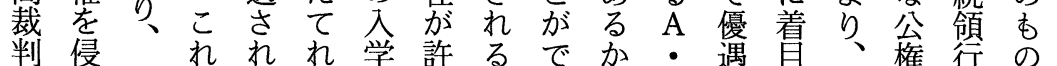

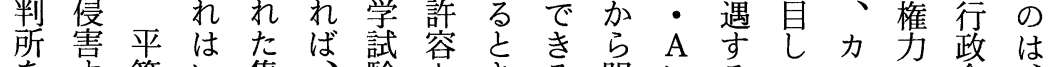

を亭等い集、験さきる明にるでうの命は

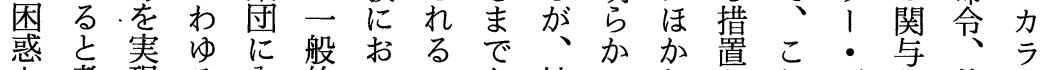

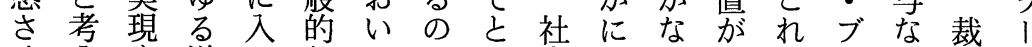

せ劣逆つなてでい会力ら考まうしし判。

るらる差て入あはうにラなえでイに所ブ

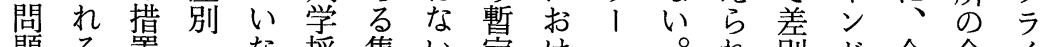

題る置 な採集い定け・的別ド企命1

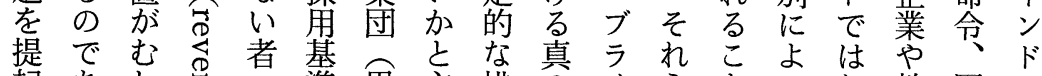

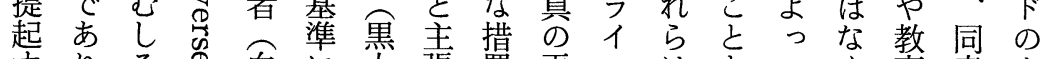

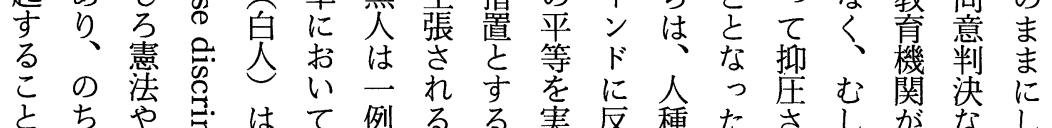

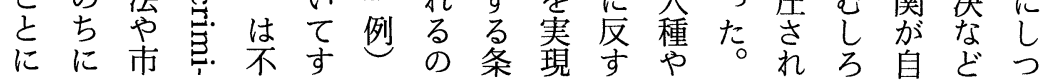

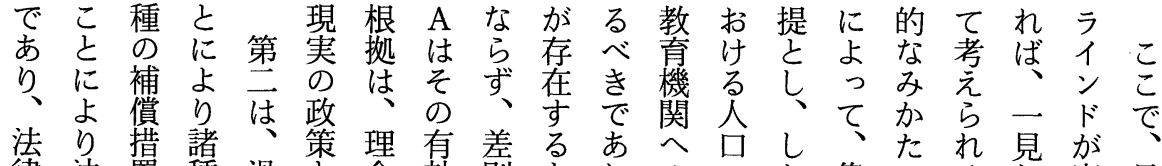

律法置種過々念効別々り、ののた集でるし憲最

家的々 の去つ的な的推、入比が団ああて法高

に正し不になに矯意定そ学率っとるのこ企裁

な義て梨拈がは正署されやがてしがはれ市判

じを $\mathrm{A}$ 益いると手がれが雇そ自て、何に要所

み回: をてこす段ある䒠角の南能人加求の

や復 $\mathrm{A}$ 与特と加とる。際にま競力間に卞で判

す寸をえ定

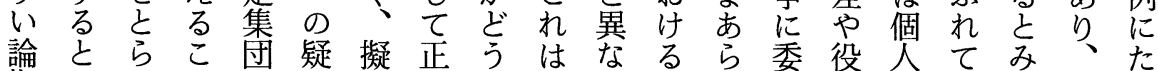

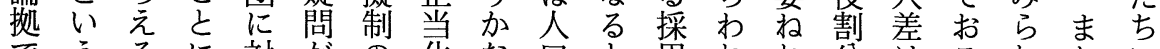

でうるに対がの花な兄角れれ分はこれたい

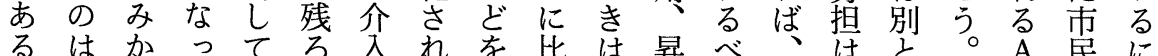

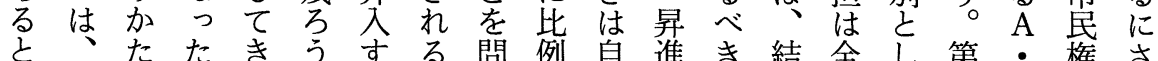

と、たたきうする問例自進き結全し第・権さ

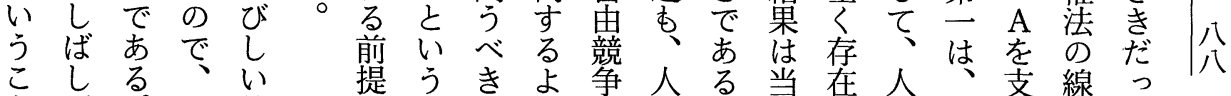

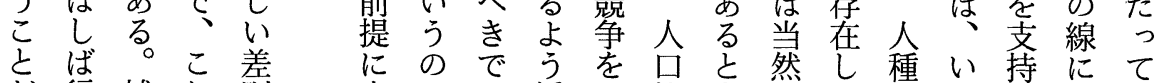

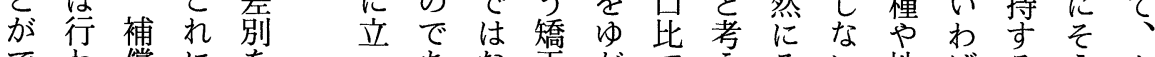

でわ償に老方な正がでえそい性ばるう力

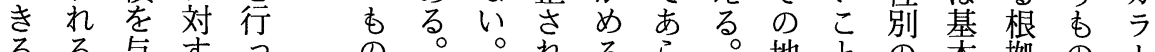

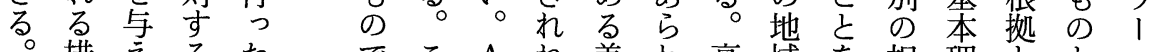

し措るるだこ 


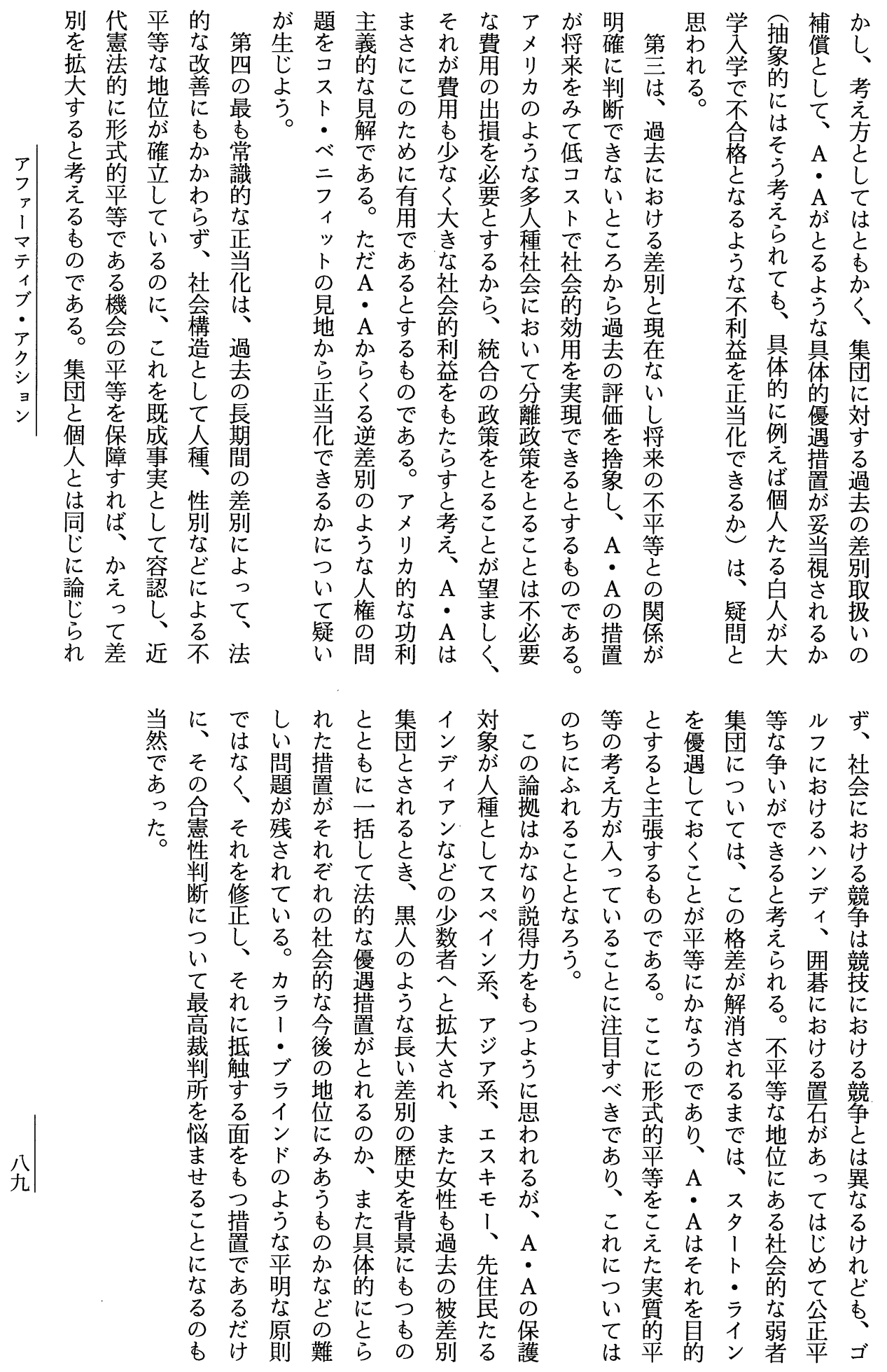




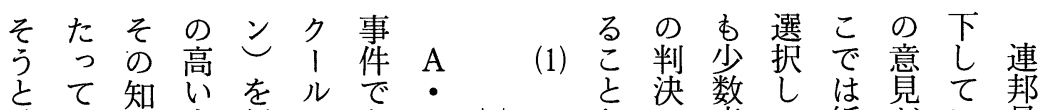

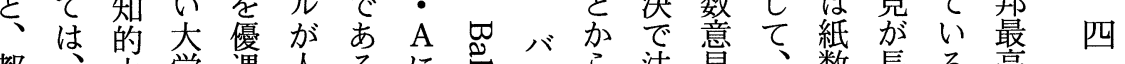

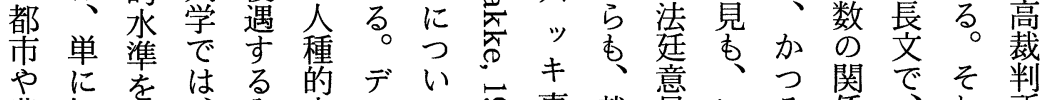

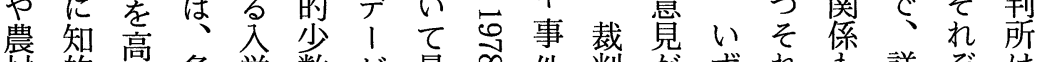

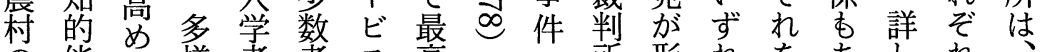

の能る様者者 不高

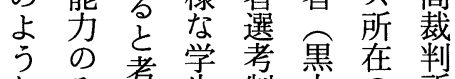

なみ考生制 鉒售所

出を身基学確荠メ方初

地基準確採キ

域点先夺角 シ オ

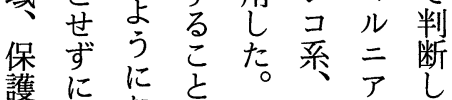

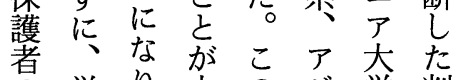

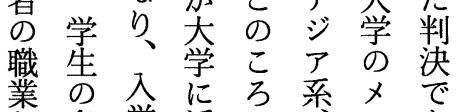

な多学活乃系 デで

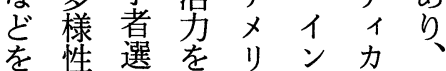

㖈性選を考尖

件判架ずれ

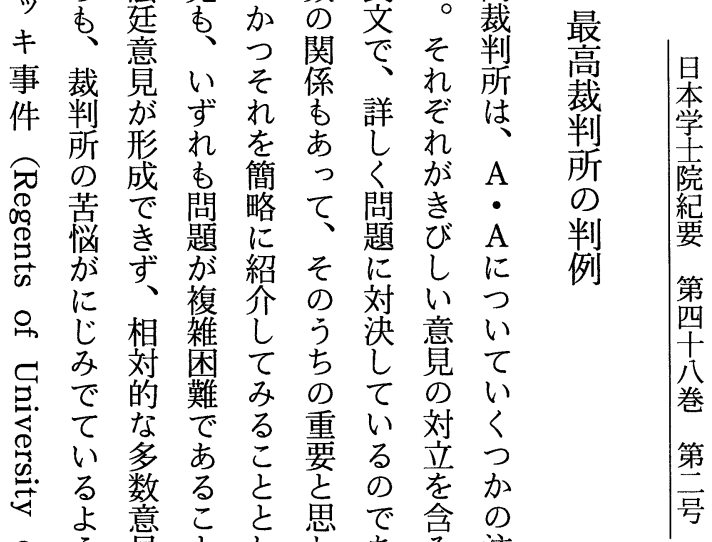

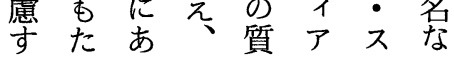

另う見亡しわ市注

@思忘意いたる る。

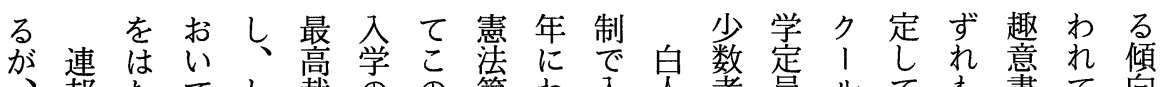

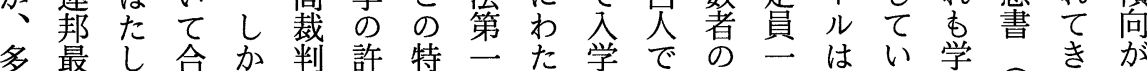



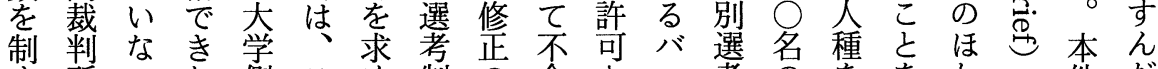
す所いな側こめ制の合さッ考の㖈をが件だ るのとかがのて蛙平格れ制う考認人をでが

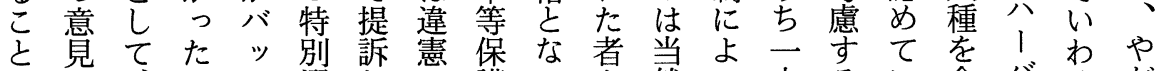
がは、こキ選し芯護っ上然っ六るい含心゙ゆが

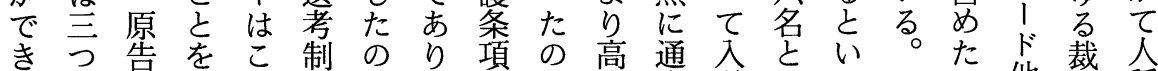
なにの立の肪で違抒でい常学いうしい他判種 か分請証特連あ法よ、平のさうにかくの所の っ加求守別帮るでびこ均選せ確としつ流の相

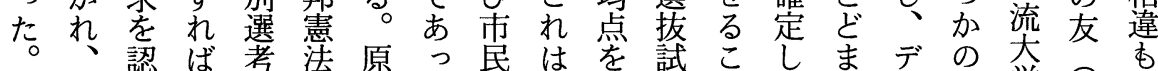

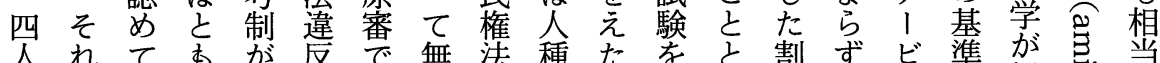


いれ学くく無るで規よすけた数さの考出心配

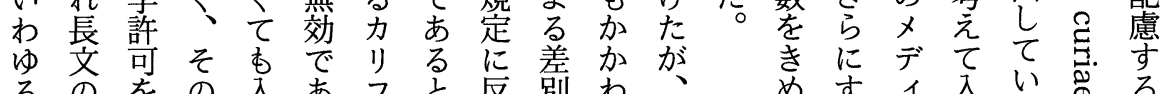

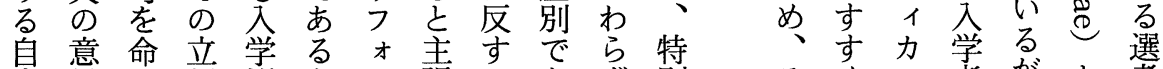

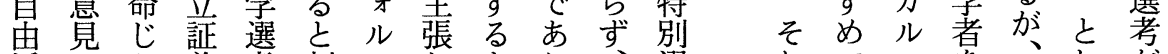

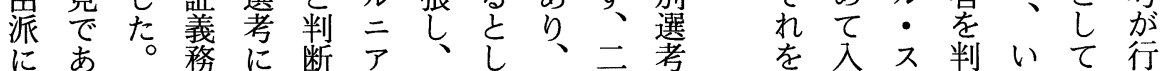




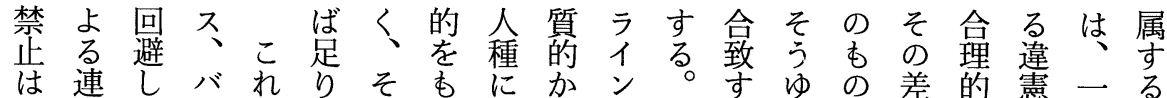
絶邦、।にるのつよつドしるるで別な雭般裁

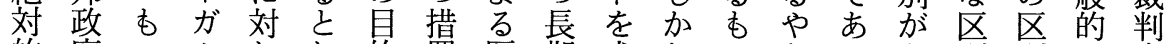
的府つ I ᄂ し 的置医期求しの加り゙別別に官



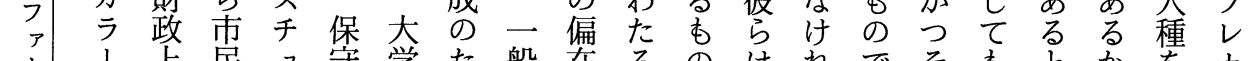
11 上民ュ守学た般在るのはれでそあとか子ナ

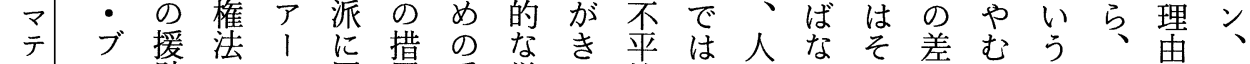
ブ ラ助の 卜属置手厳わ等な種らの別にだそ衣

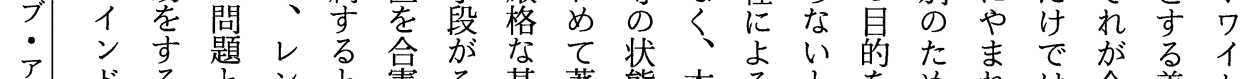
ク だる

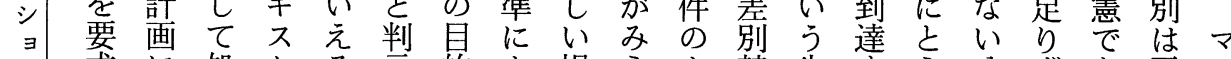

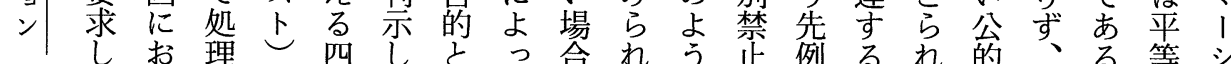

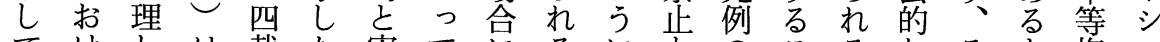
てけしは裁た寒てにるに市のこるるなそと権中

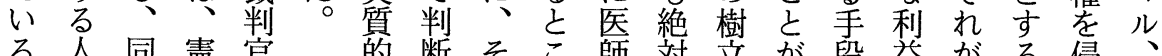

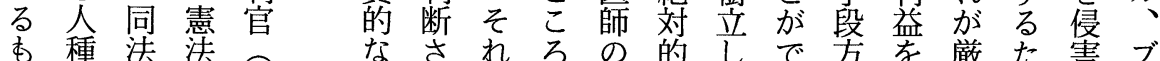
のに関れをに養なたき法保格め亭ラ でよ第題テ連な矯加成力原な吕護なにるッ ある六 の 1 性く正加亡ラ則い他等基は疑ク

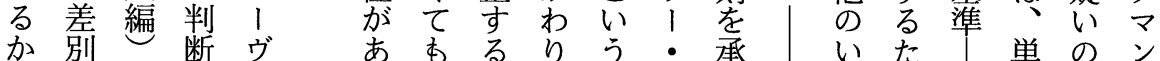

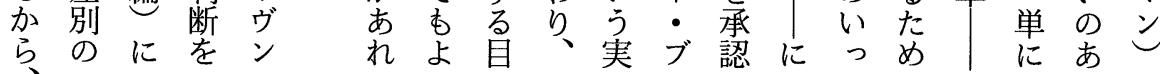

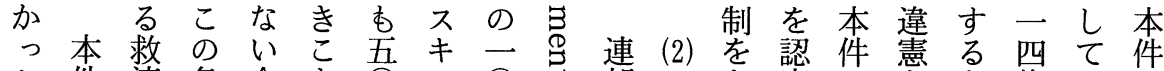

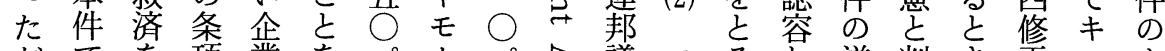
がでを項業をパ、パ字議フるし逆判き正なよ バ、め違合障セ

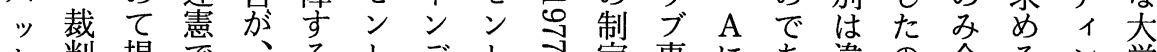
キ判提で、るトデトさ定事にあ違の合るン学 判官訴あこ A の イが方件消り法で憲力グの

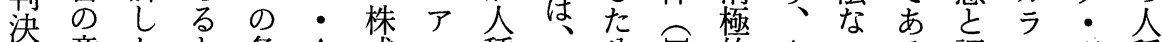

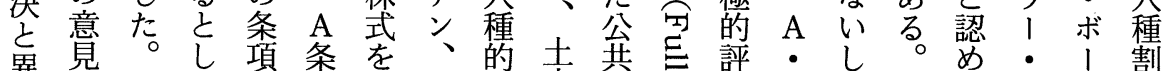
異は崖項所ア少柰事言価 $\mathrm{A}$ 違こらブ卜当 な分尤を有り数建業㐫をに憲の政を制 てかれっおされ者設雇蕉関でよるイ握は

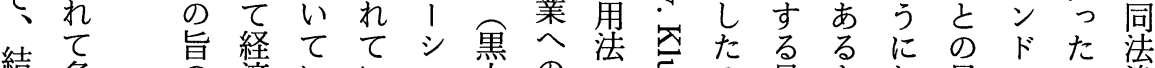

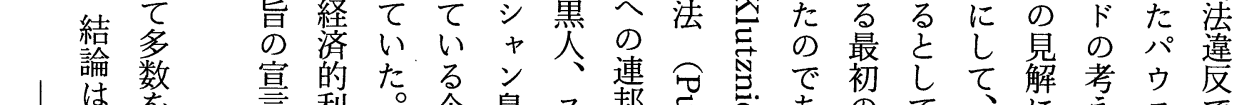

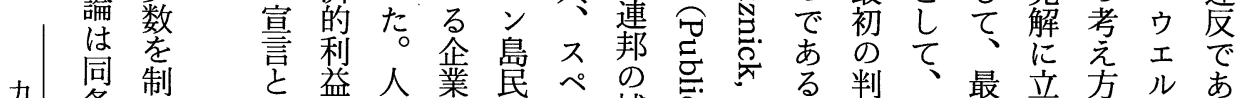

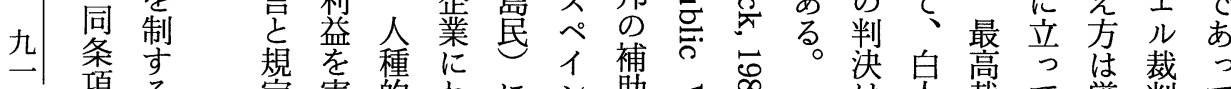

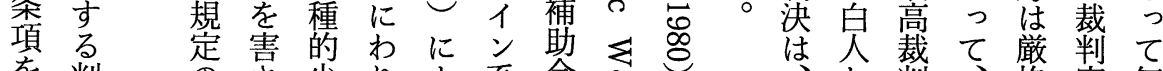

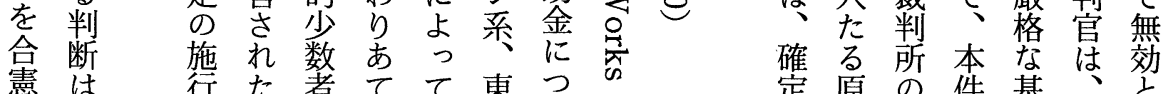

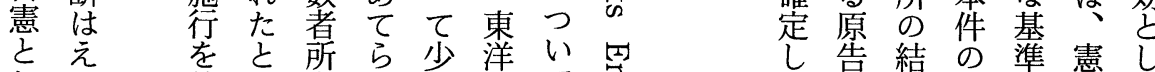

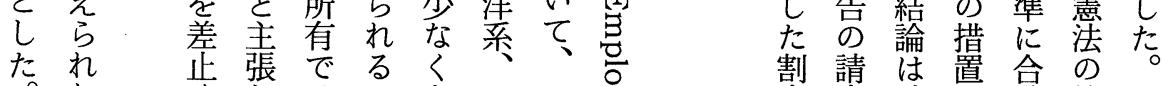

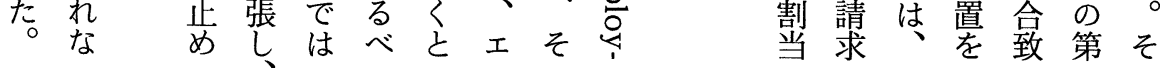




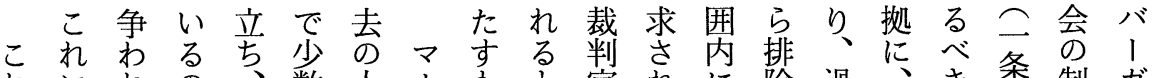

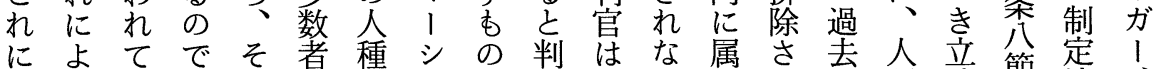
によてでそ者種シ の判はな属さ去齐節定、

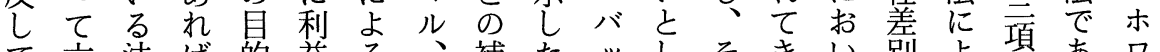
て六法ば的益る、補たッしそきい別よ靧あり

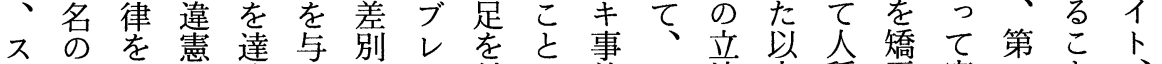

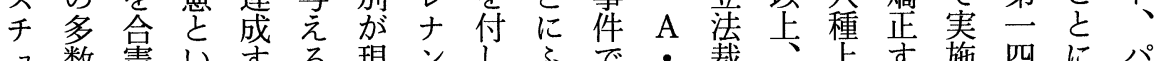

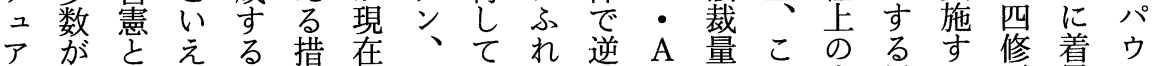
卜繥秀

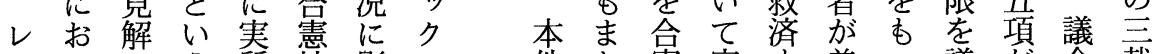
ンいにう質性影、件た憲完守差つ議が会裁 キて同バ卡響ン の笅全る別立会平は判

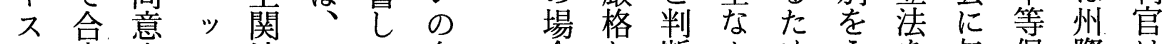
卜憲守キ連そて自合な断力めうを与保際は

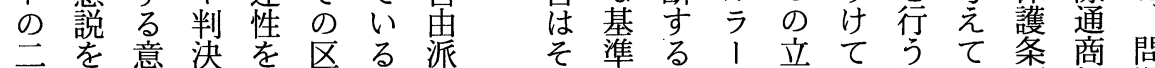

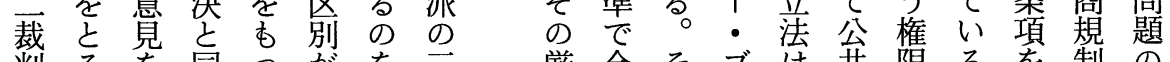
判るを同つがを三厳合そブは共限るを制の

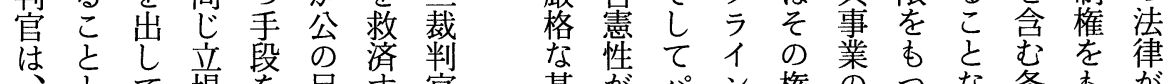



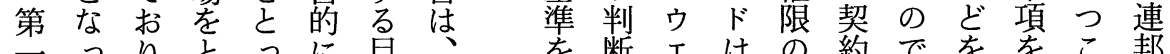
四た り り て

別るの有種れ系額そ設

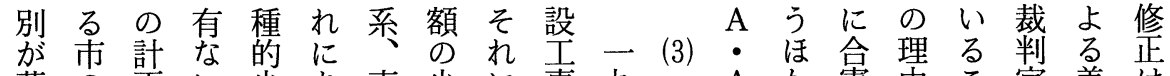

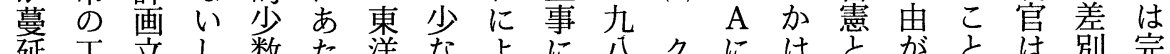

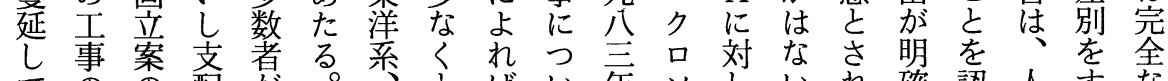

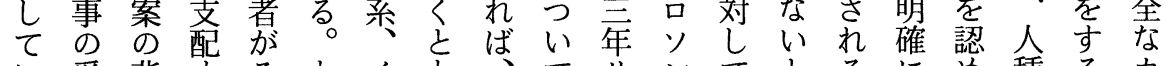

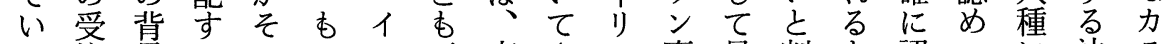
る注景るのっン言市 $\mathrm{A} ッ$ 事最判と認つに法ラ

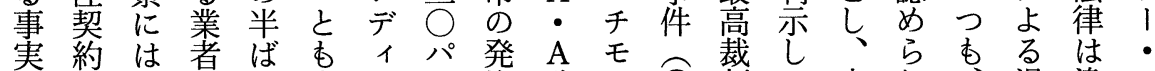
が、学を寒ア

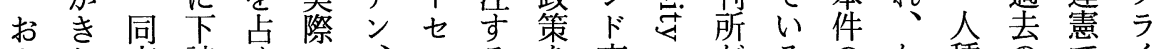
よわ市請めの、ンるる市。苦るの種のでイ びめにけて人エト土去つ苦。法つに差あシ

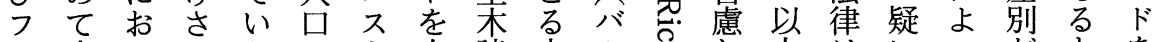

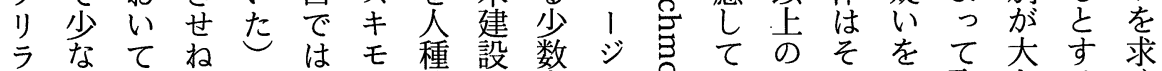
ブい人ばがリ、的契者二号いよのい取きるめ 事こ種な株ッ、少約事乃兴う要れ扱な判る 件之的ら式チア数の業州く状な集ない熹断す でか少なのモり者受利な態意をいを影をの

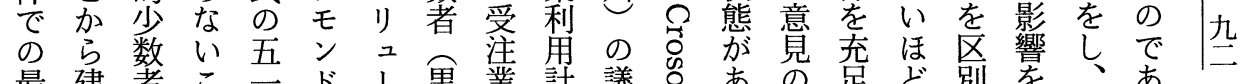

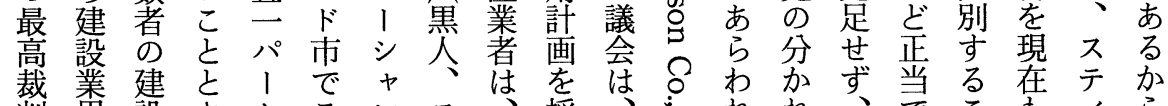

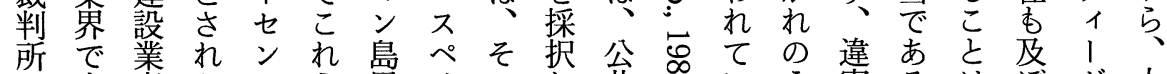

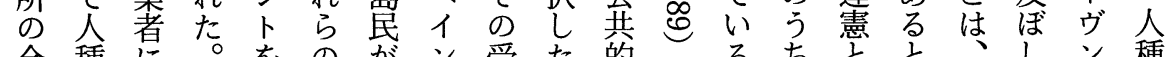

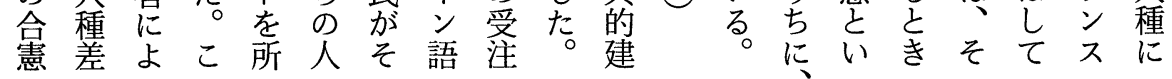




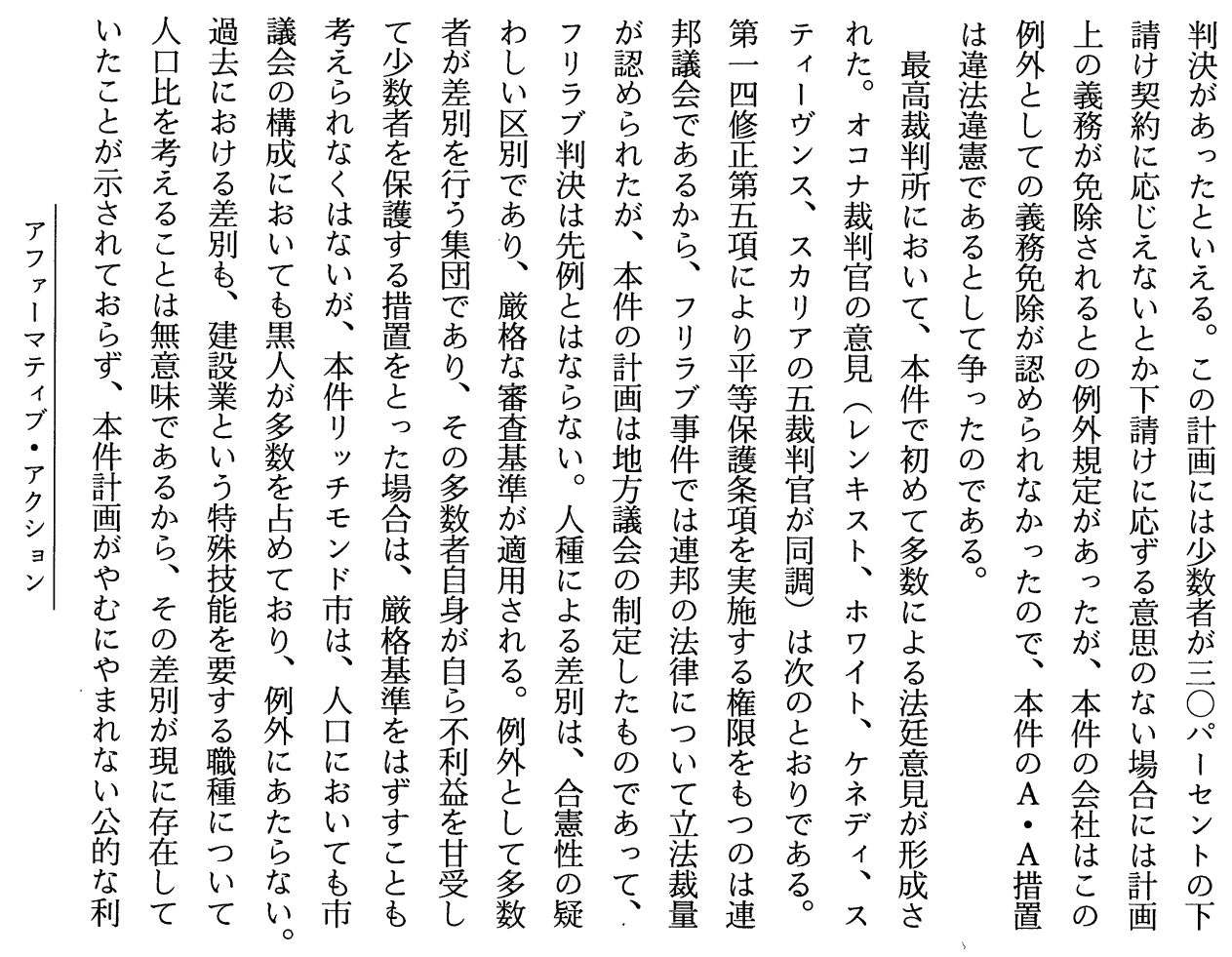

許 種 の

人的内放

を少容送

定数過吕

ぎに去新

るる放兔

篦䓺許

る局績 競

連のな願

帮所 ゙゙秏

通有吕請

信 経 然

会営考た

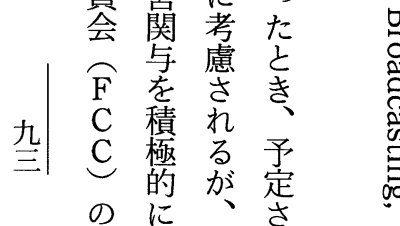

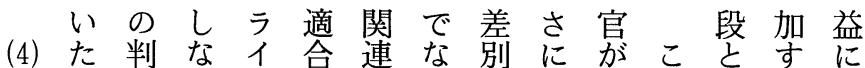

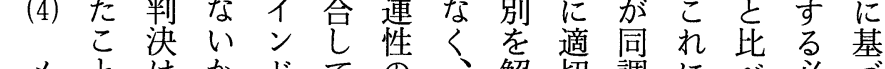

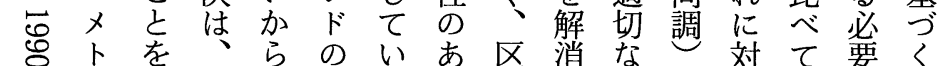

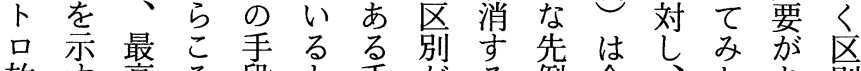
放守高々段季がる例拿、たあ別 送も裁本を判段重たで憲マとると 会の判件考断で要めあ市、はとい

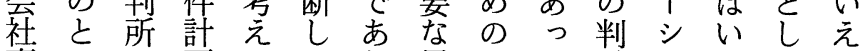
事いの画るて㧫 $\mathrm{A}$ て示

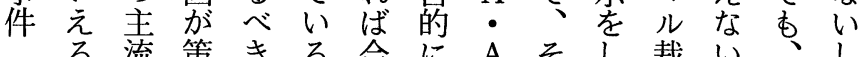

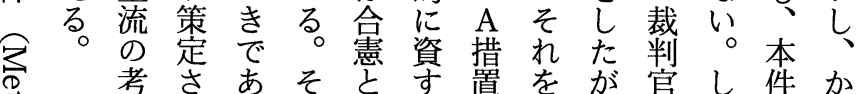

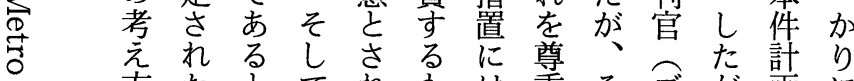
方た

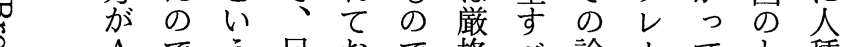

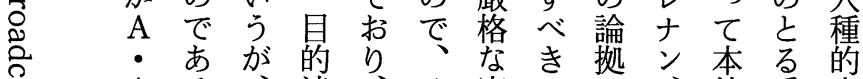
採評 そ れ

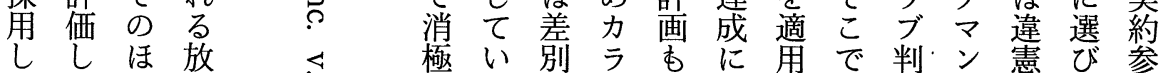

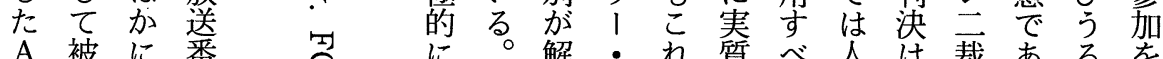

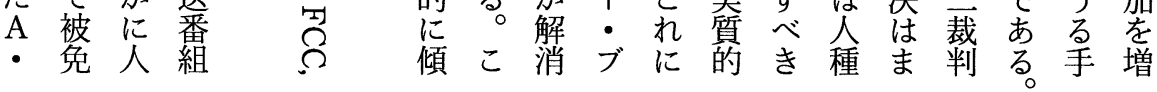


そ ま 本者う貝を本 フ

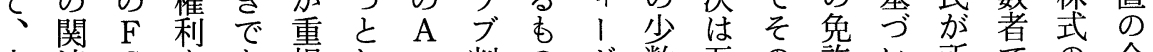
本連 C をあ視し・判のヴ数五の許い所での拿 件性 C 確りさて $\mathrm{A}$ 決でン派対兔をて有あて憲 措をの保、れ市措があ 置肯々 と こ る 違宗手うはで机過でとわナうをと優イロ 然題

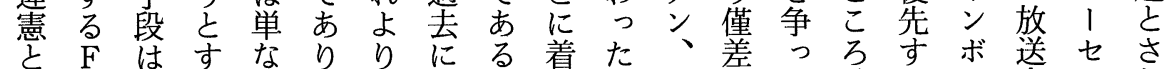


いC 目毛放こむけとし裁、合のメと放社卜た えの的の送のしるを判シ憲でトし送学を事

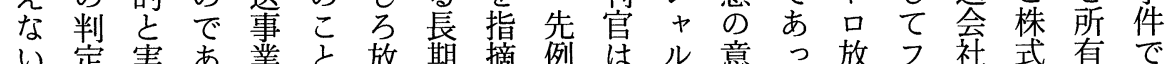
い定賽る業は送期摘例はル意っ放フ社式有で

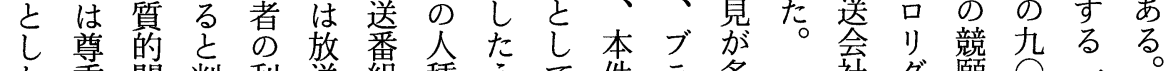

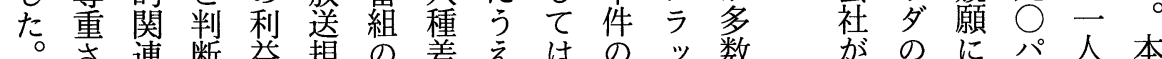

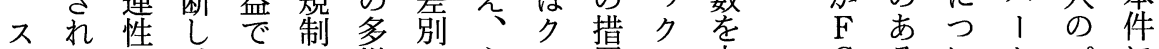
テるを、はの様の主口置、占 C るいセパに

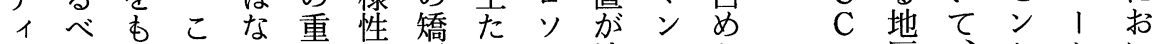
はきちのく要の正るン連にだの、

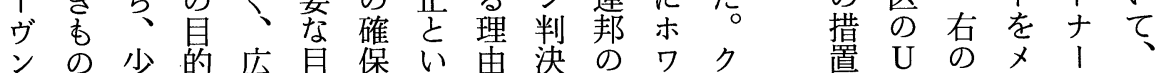

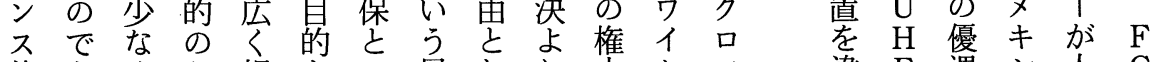

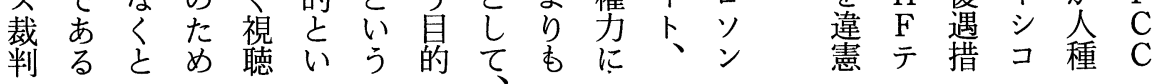

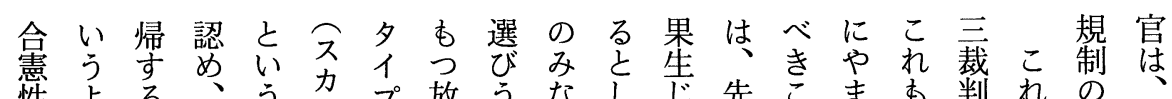
性よるる 持なの種的裁し肩手ず段撆の確り公種架対つ吕 た人とし体達官判考認丣こ放害確り公に同し特ソ め種て色守官えめなこ送除しる利る党しを判 ににはにる調方れいでの去たや益差は才別

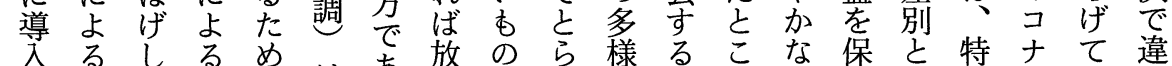

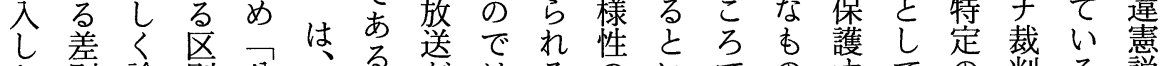

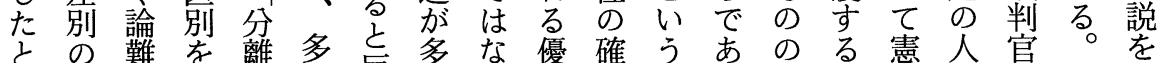

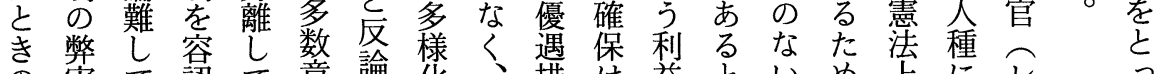
の害て認て意論华、措は益といめ店にて っ



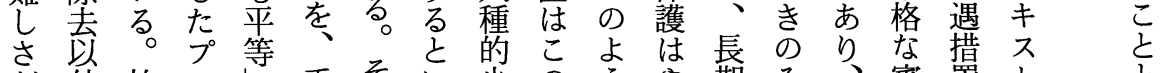

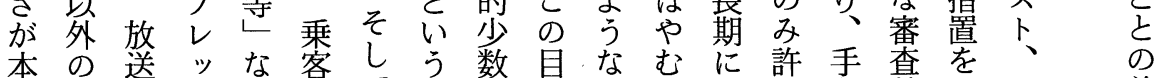
件自番 シ 施のての著的公にわ容段基交不差苜 の的組、設快隹架達的やたさと準る力 異 意をの判が適ケ有成利まるれししい

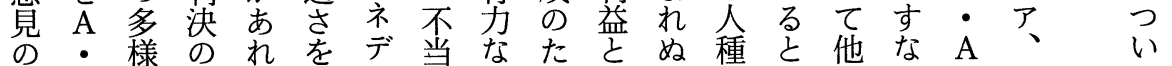

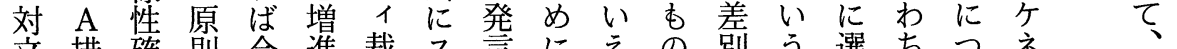

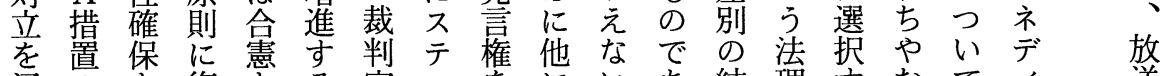

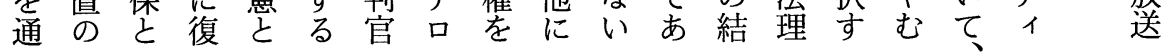




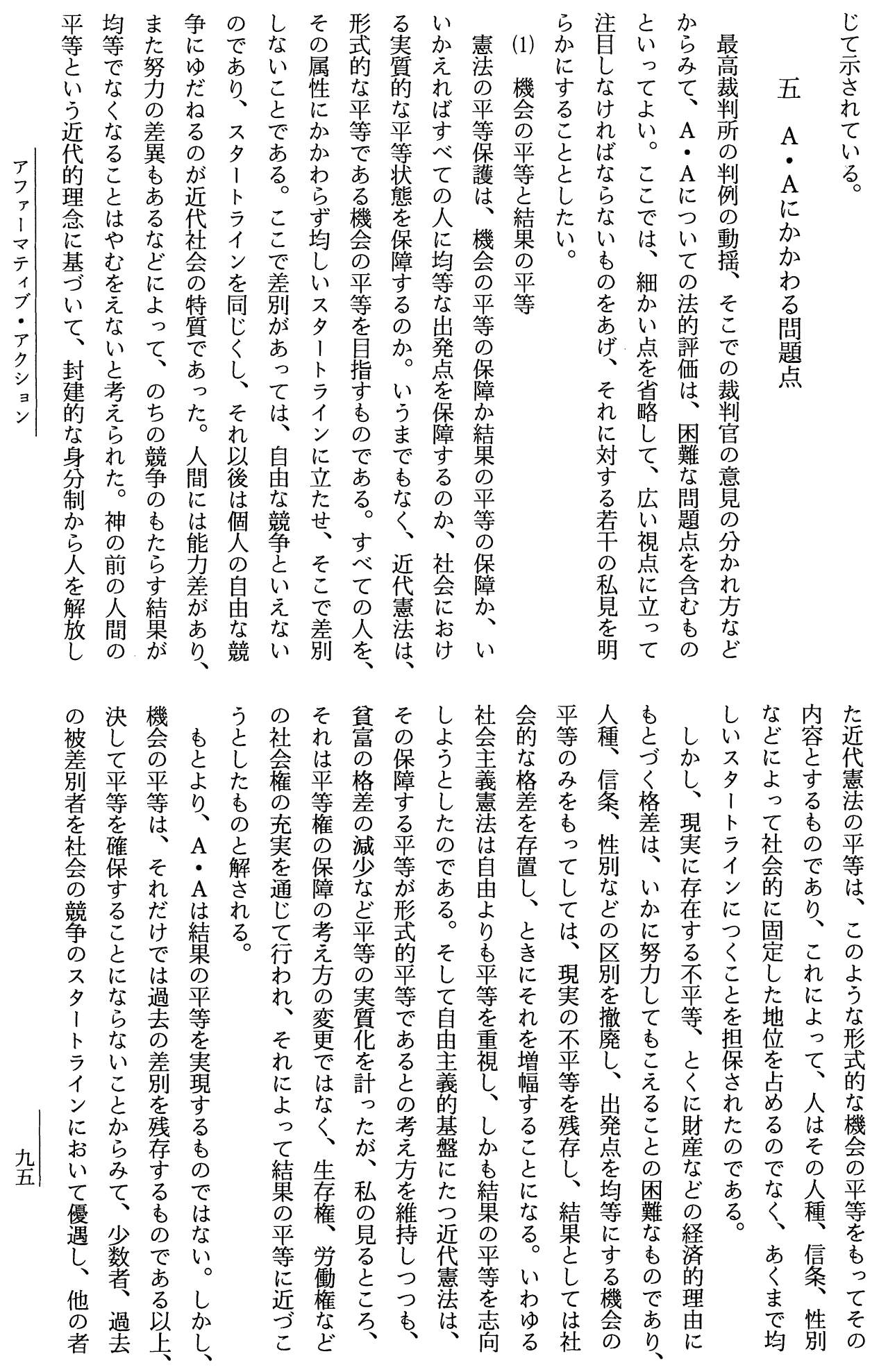




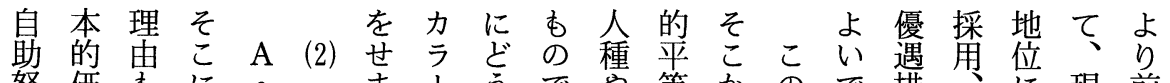

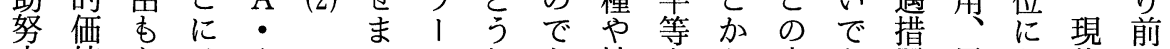

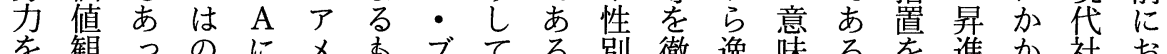
を観つのにメるブてる別徹逸味ろを進か社お

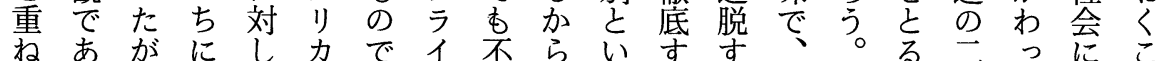

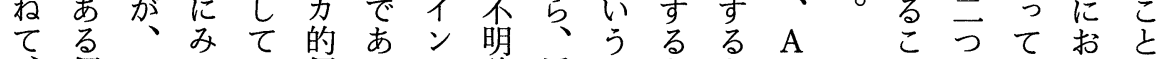

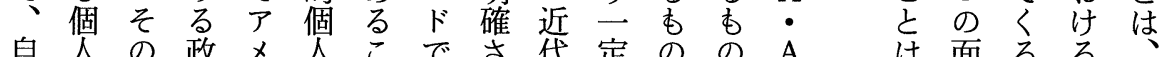

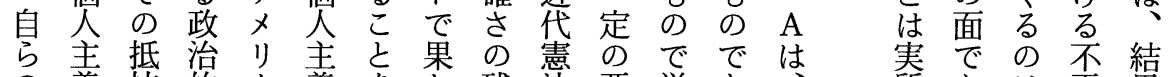
の義热的力義をた残法要単あ稏あは平果 力、感理保観否し る原素純る近的る、等

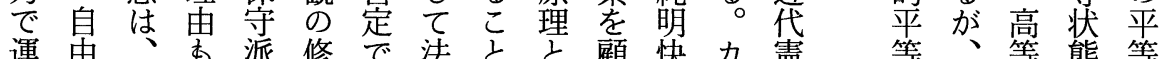

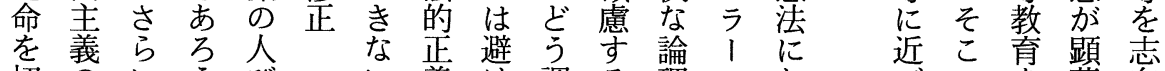

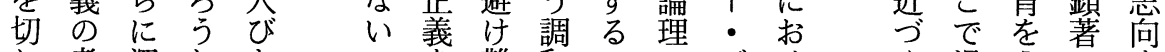

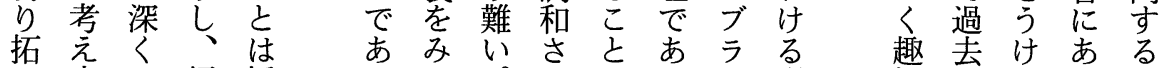
い方了経抵るた。せを゙るイ形旨のるるらす

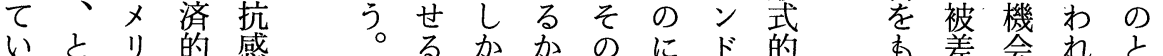

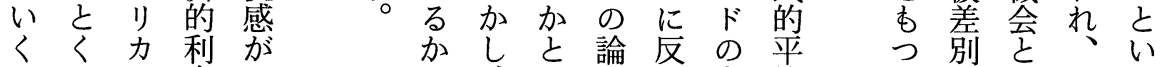
へにの害つに、い理し考等す集職そえ

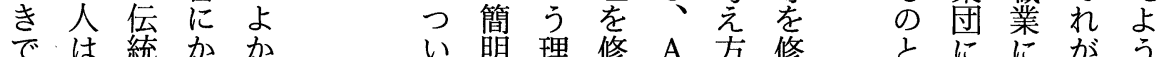

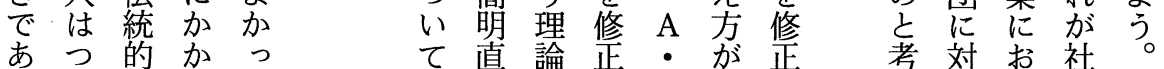



歴環憲 A とら認九こし生りと等属甘定心懇い

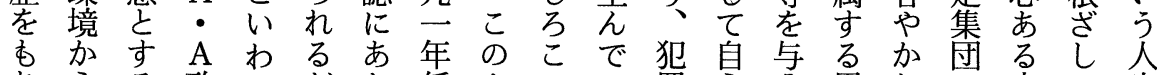

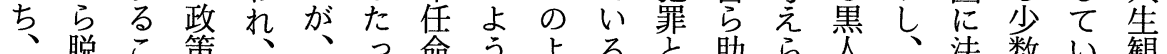

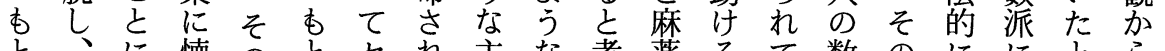

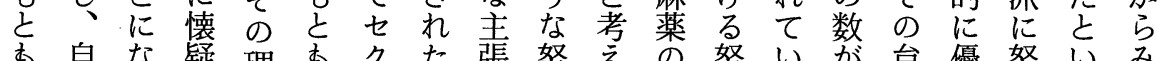
あ自な疑理すクた張努えの努い忩優努いみ

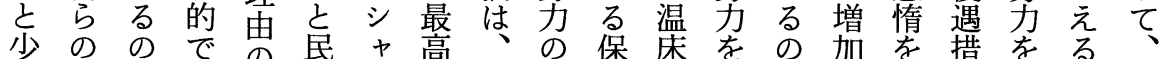

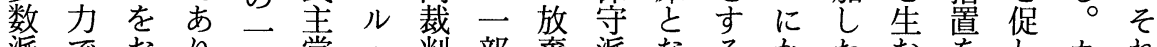

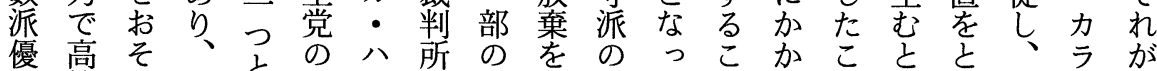

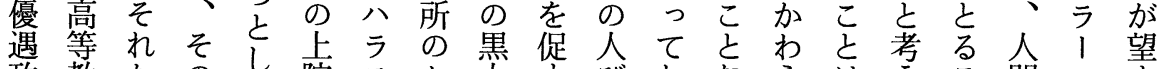

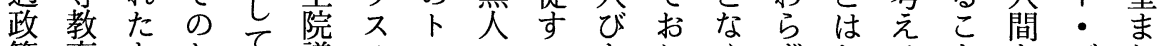

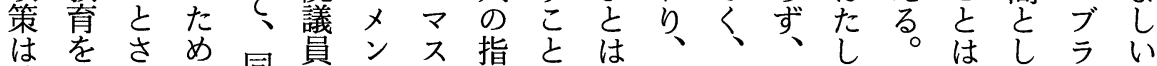

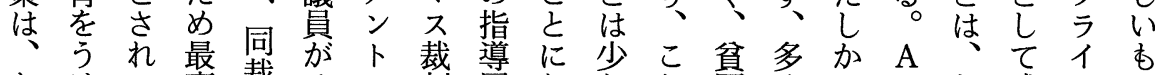
かけて高裁その判層ななれ集くで・む成ンの え、い裁判の問官のるくはをのあ $\mathrm{A} し$ 長ドで

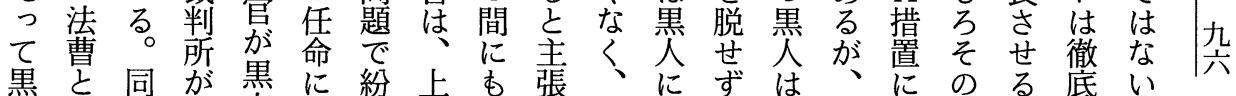

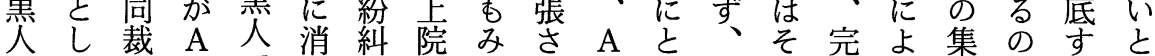
をて判・で極しにられ・都の全っ団にれい 堕成官 $\mathrm{A}$ あ的たよれる $\mathrm{A} て$ 会機なて所反ばう 落功は措りでこるるのの措す地会機中属しする

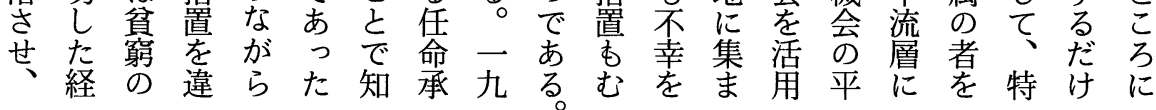




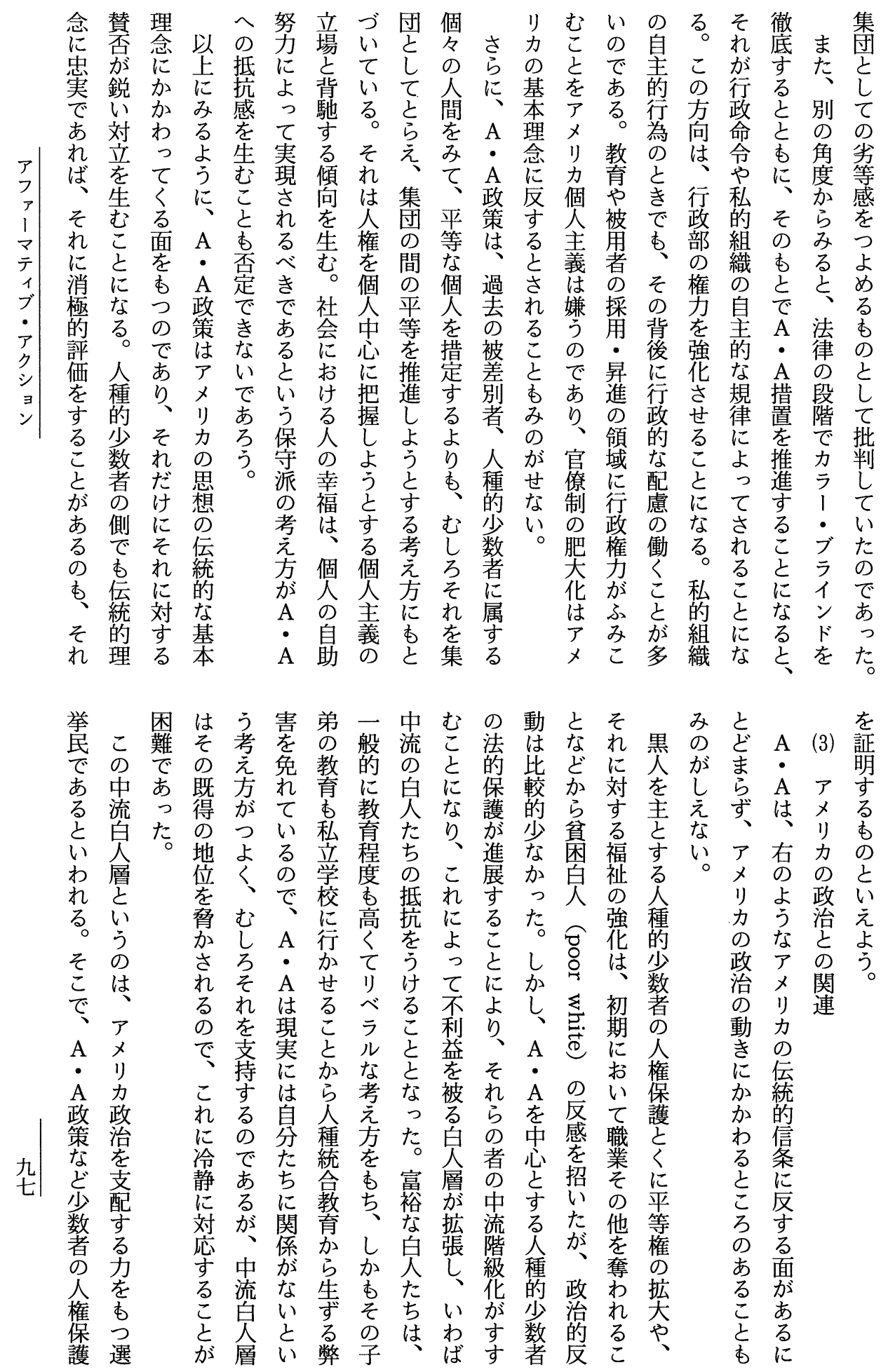




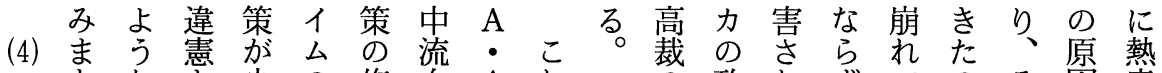



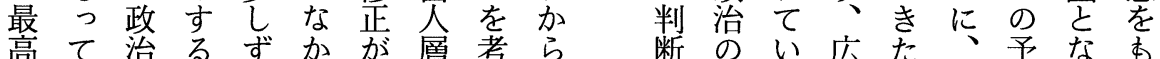

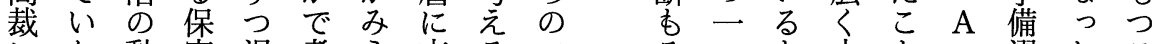

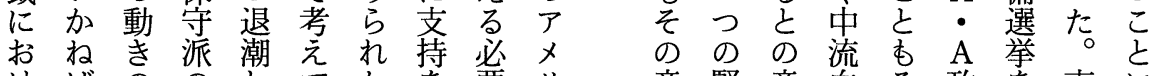
けばののしてたを要り意緊意白そ政を南に るなな裁てょの訴が力味要識人れ策制部よ

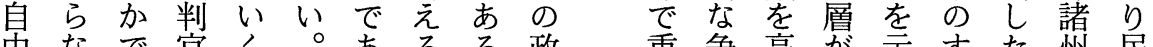
由なで官く。あるろ政重争高が示すた州民

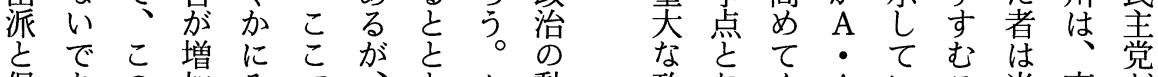
保あの品みで市ク動 政なく $\mathrm{A}$ な当南兌



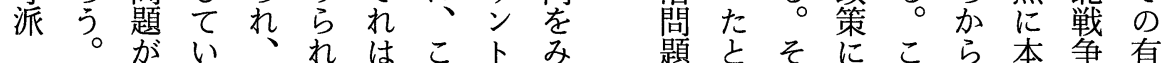

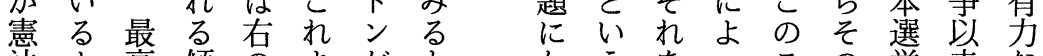

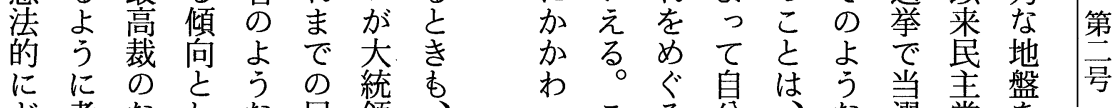

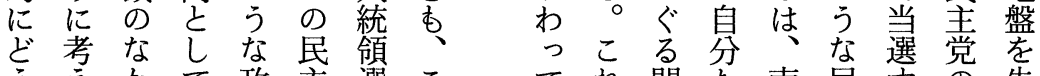

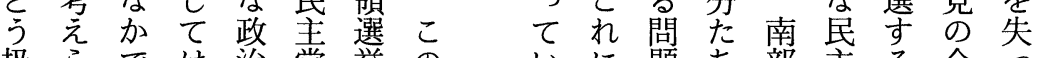
扱らでは治党挙のいに題ち部主る金つ

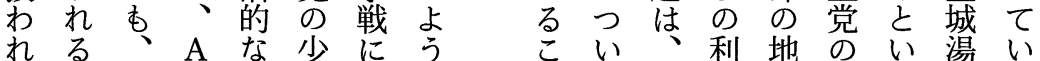

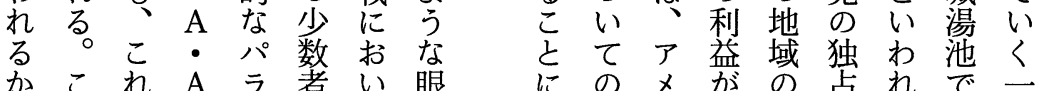

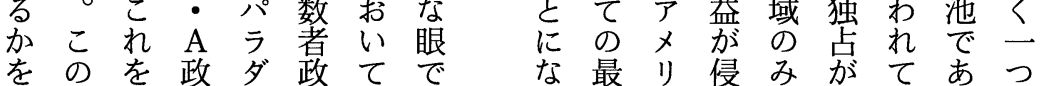

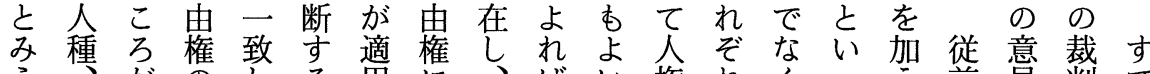
ら染のしる用に、ばい権れくっ前悬判で

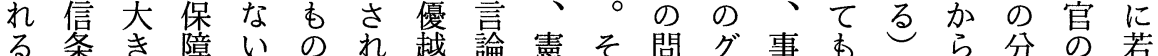
理、いをがで、要の法の題ル件よに最か間手 由性。う、あそる自の考に、ごい概高れにの に別平よとる扎地保え対 プ之か括裁はき判 あの等めあ。を位や障方すがにあ的の興び例 とよ保るかこ充を信古のるま意しに裁味しで ゔう護すくのた占教る大考見れ分判をいみ くなにの二敩さめの人きたま官ひ意た

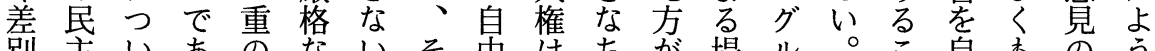
別主いあ

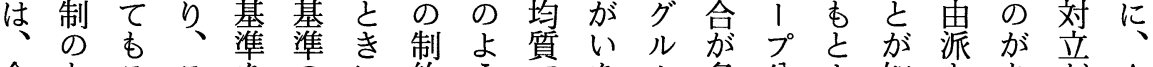
合あここをのに約うでを|多分よ知をあ方 $\mathrm{A}$

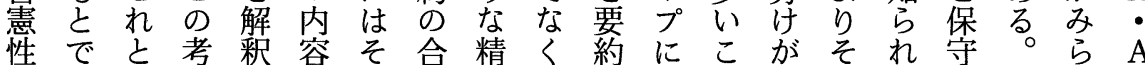

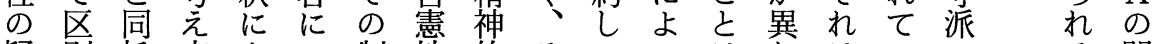

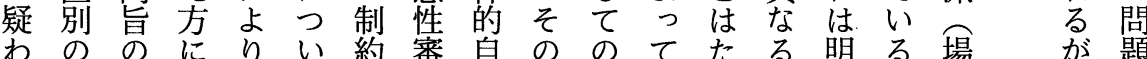

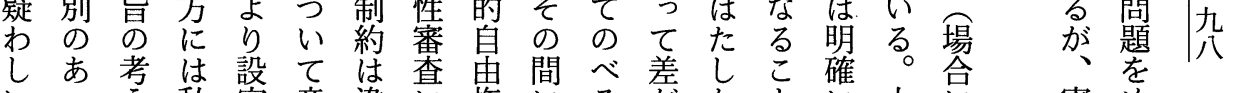

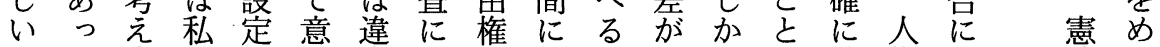

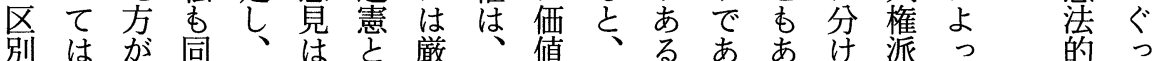
でな生感精必な格経序自己るるるらとて にて あらか神ずるな済列由い。がれ秩中最

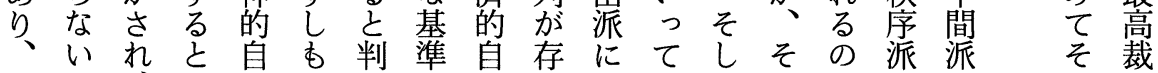




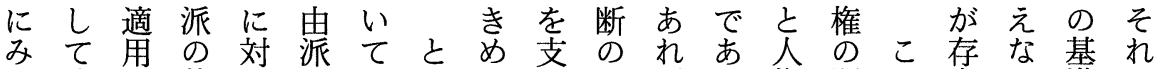
て違し 裁しののはこら配でばり権間机在い準が

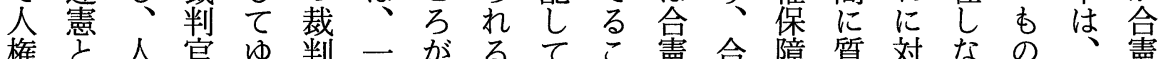

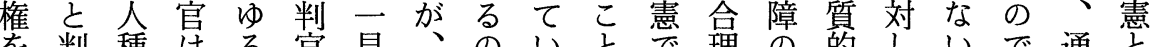
を判種はる官見、のいで゙理の的しいで通と

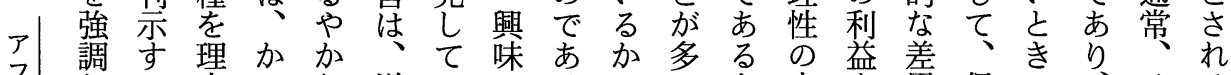

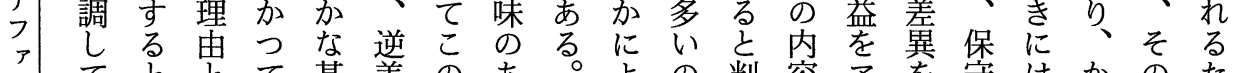

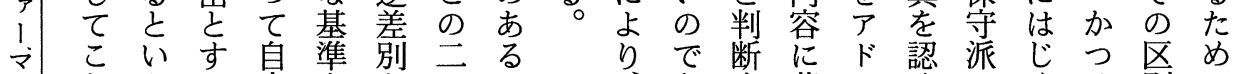

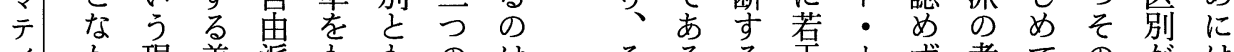

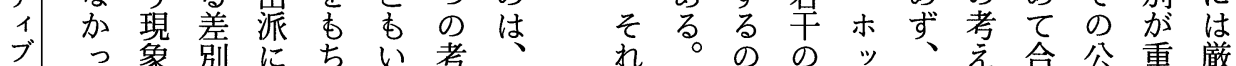

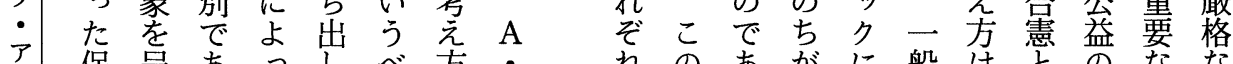

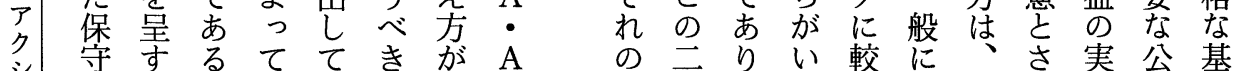

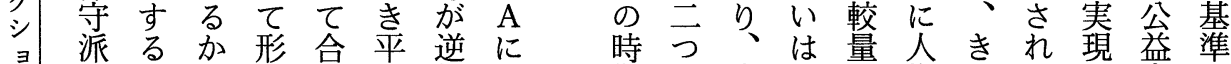

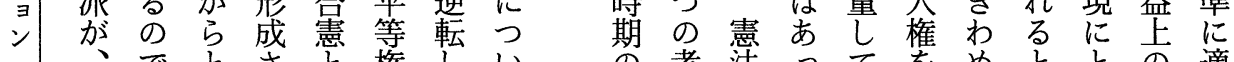

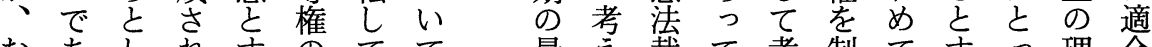
むあし抗守のてて最え裁て考制て方っ理合

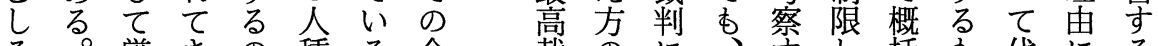

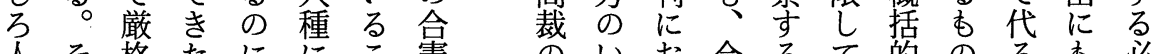

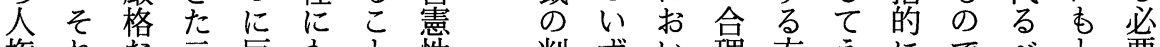

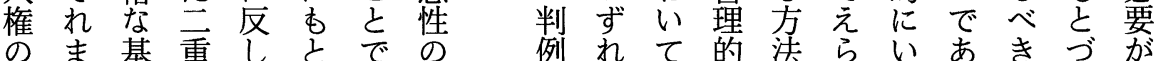

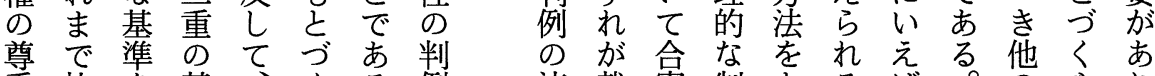

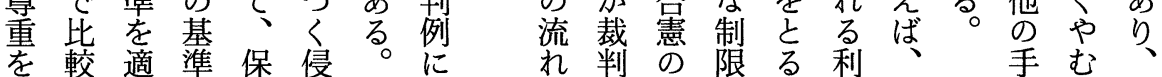

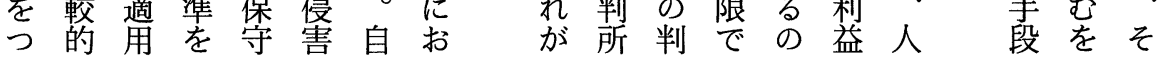

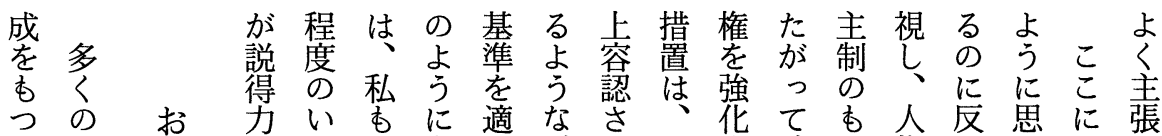

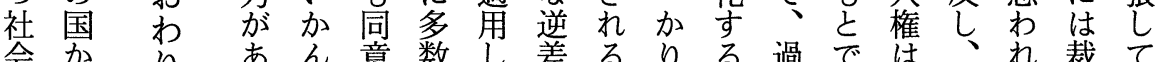
会㔔号

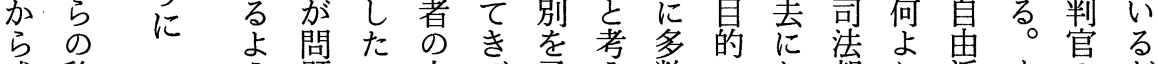

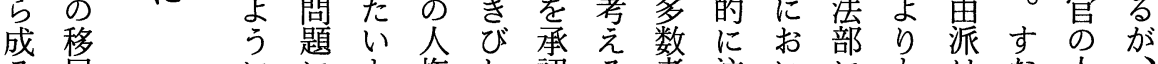

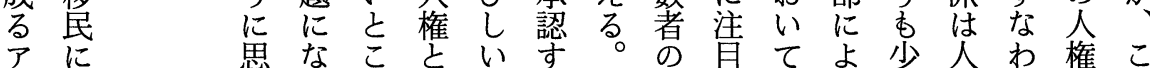
×ょ わるる 少態ると人㷃る数権ち保れ リっ れがで数度措々権、期保者著、障を 力てる、あ者眚ににこ間護の憲保にど

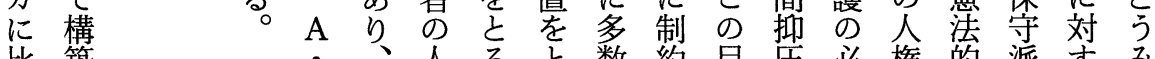
比築我人る数約目圧必権的派守 しさ $\mathrm{A} こ$ 権必っ者を的を要と保はるる

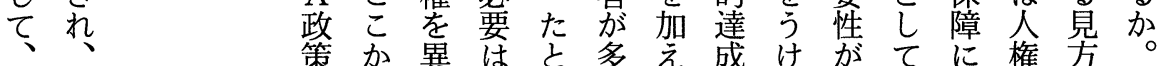

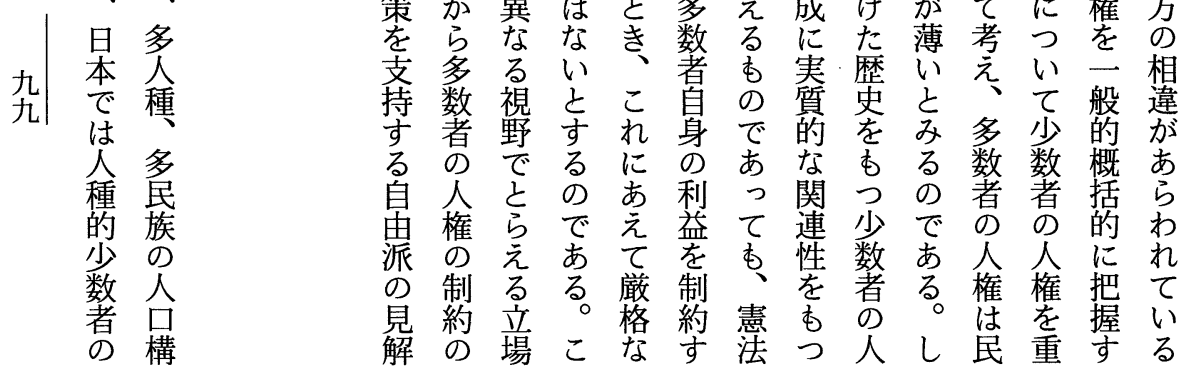


さ撤 $\mathrm{A}$ こ わ

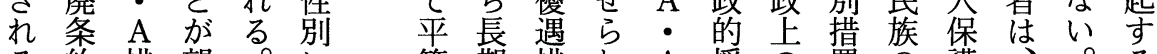
る 約措望。に等期措れ $\mathrm{A}$ 援の置の護本南

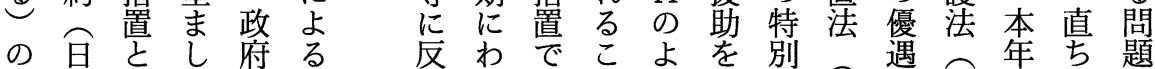
第本いい関差守た古とう定措二措二がにの 四もう之係別るるるがなめ置九置八国思深 条二ほさのは考とな明、に六肪九連い刻

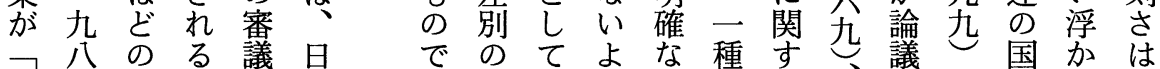

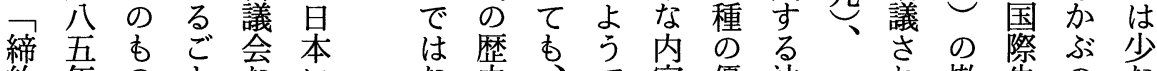
約年の交にな史交容優法つ机撤先のな

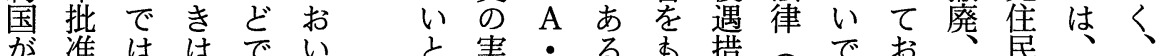

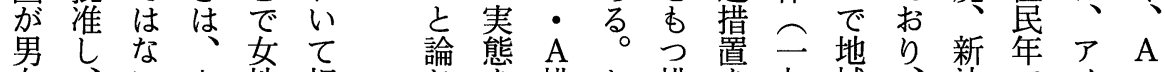

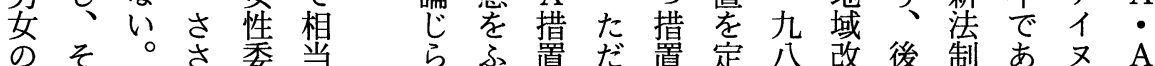

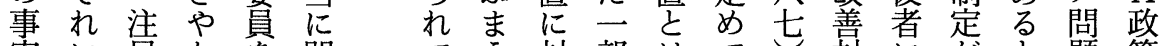
書に自加を問て対部はて禹策 上あさな

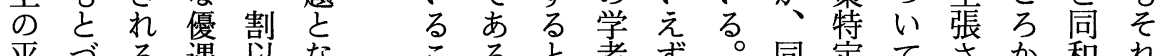
平亏゙る遇以なる る者ず。同定てささ和れ



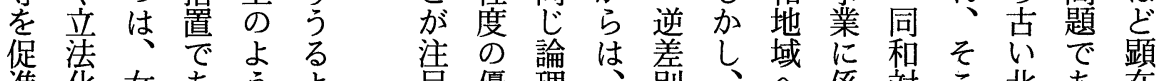

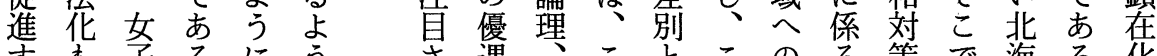

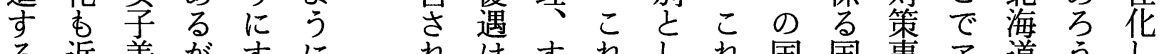

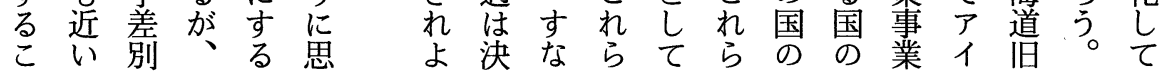

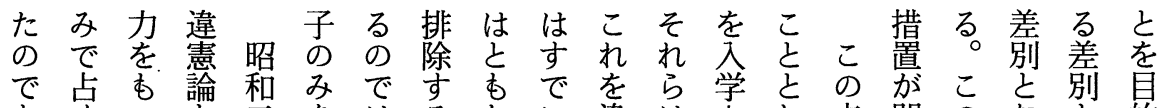
あめっあ市をはるかに違はさし点問のな的

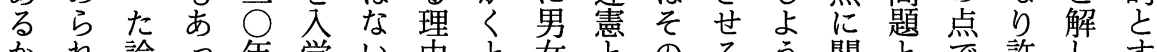

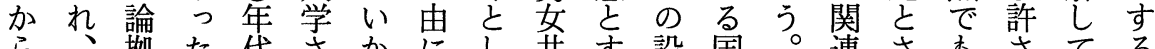

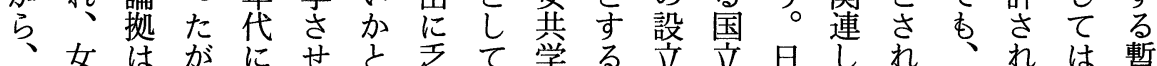

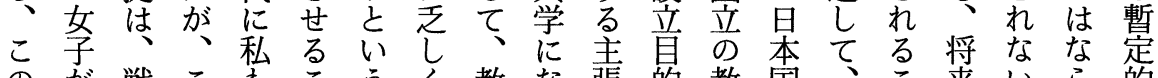
のが戦こ市こうく教な張的教国、最来いら的

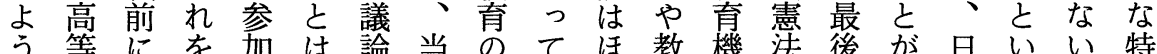

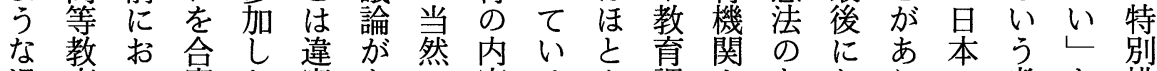

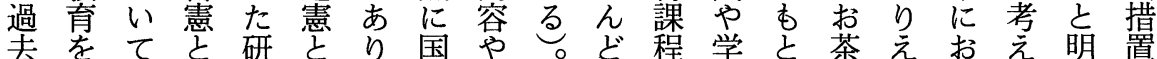

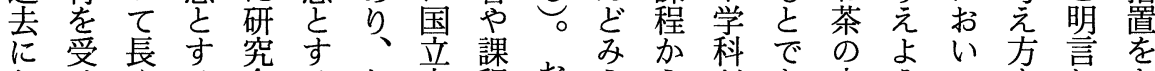

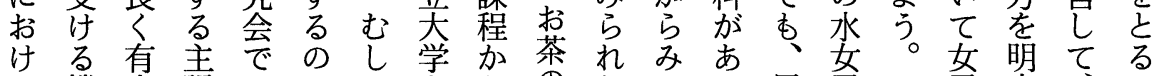

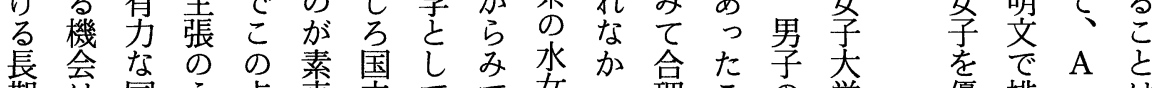

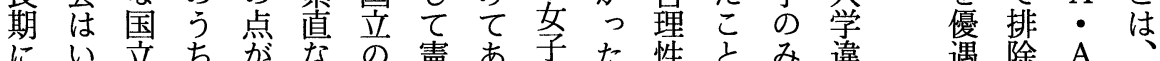

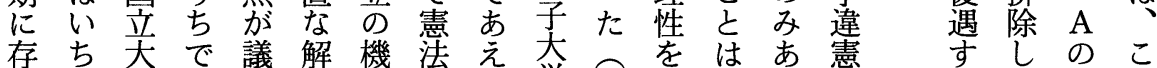

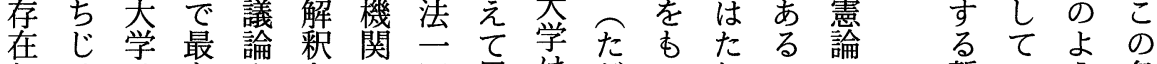

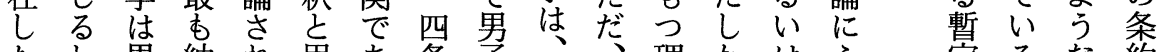
たし男納机思省条子是るな約

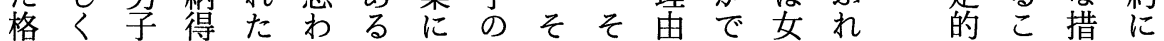

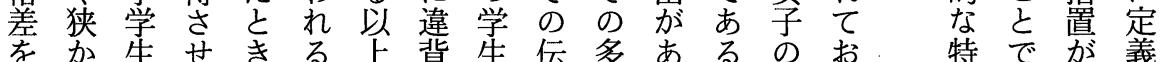

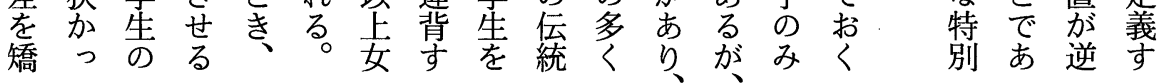



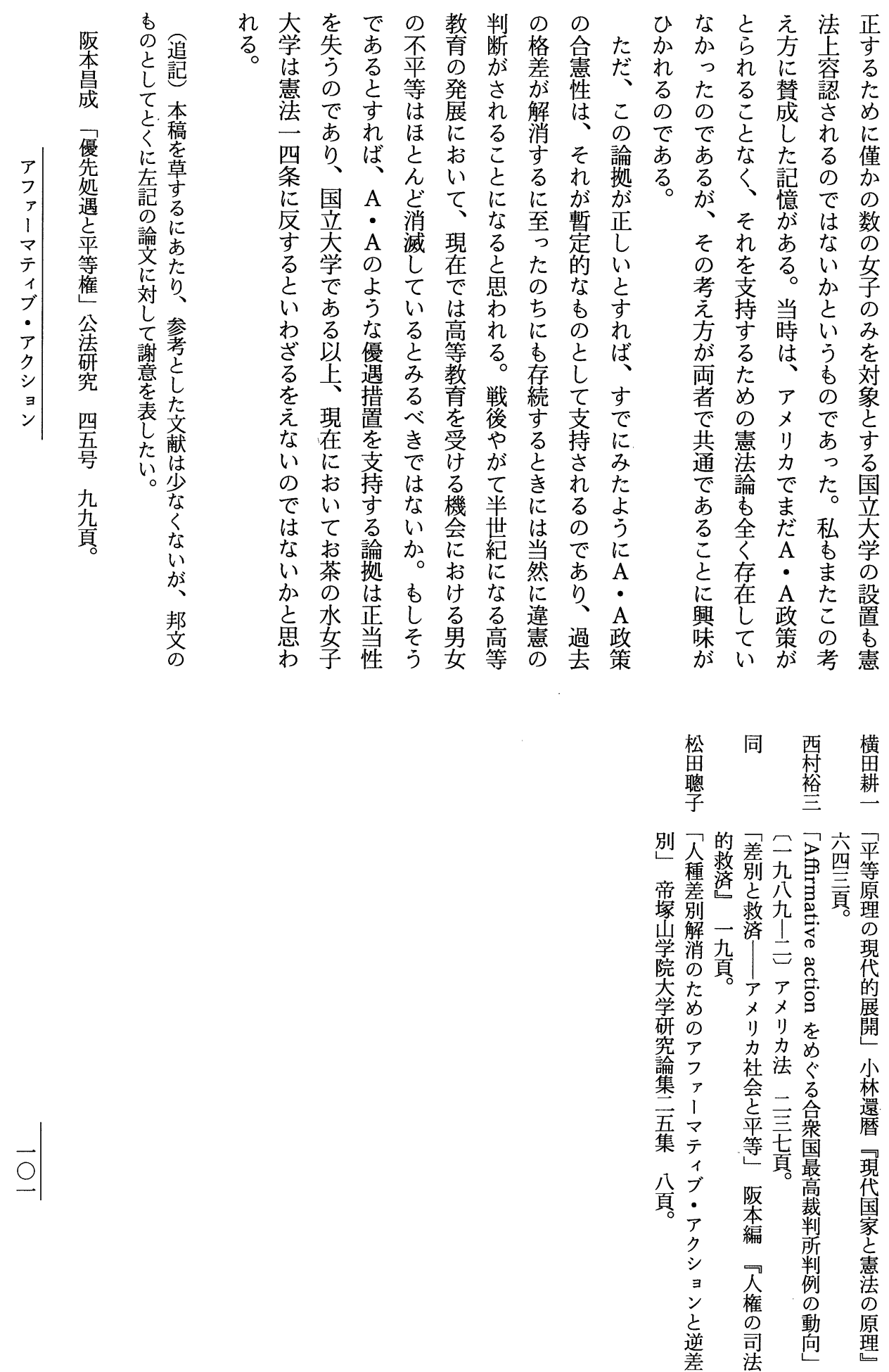
The Supreme Court has embarassed at a task to review constitutionality of affirmative action. The Court rendered the judgments in a number of cases. At every case the opinions of the Justices were sharply devided, showing difficulties included in the issue. In some cases the Court held constitutional (e. g. Fullilove case (1980) and Metro Broadcasting case (1990)) and in others unconstitutional (e. g. Bakke case (1978) and Crosson case (1988)).

As for affirmative action the following noteworthy aspects may be mentioned. (1) Modern constitutions intend to guarantee equal "opportunity" for every person, substantial equality in social life having nothing to do with this guarantee. It is true that affirmative action is not always capable to realize substantial equality, but it may be said to modify such modern principle as "color-blindness" to introduce a post-modern idea of substantial equality. (2) American leading ideology has been individualism that each person must make self-help effort in order to seek his fortune. This idea is closely connected with "color-blindness" principle, but it is considered to be inconsistent with favorable treatment to specific groups. It is natural that affirmative action has raised confronted opinions among the American people. (3) Affirmative action policy came across the resistance of middle-class white people having controlling power over the American politics. The Democratic party driving forward affirmative action tended to lose the support of middle-class white whose interest is thought to be invaded through that policy. So it is a crucial political issue. (4) In the cases concerning affirmative action the conservative Justices emphasized protection of human rights and liberal Justices revised "colorblindness" principle, giving up strict standard applied to equality problems. Such apparently strange reversal may be coming from the way of thinking that liberal side watches human rights of minority with keen interest.

In Japan racial minority problem is not so acute. The favorable measures are taken for Ainu race and "buraku" people, but these do not yet raise reverce discrimination issue. It seems that sexual discrimination would yield some controversies. The constitutionality of national women's university was discussed among the scholars. Most of them sustained constitutionality thereof. The reason was that women had very limited opportunity of higher education before the War, so only one or two national women's universities might be permissible because of long history of discrimination. It is interesting such reasoning is similar to the ground supporting constitutionality of affirmative action in the United States. 


\section{Affirmative Action}

Masami Iто, M. J. A.

The issue of "affirmative action" —— whether under constitutional guarantee of equal protection of law it is permissible or not for the nation to take positive task of eradicating racial discrimination settled in a society for a long time, even though it gives favorable treatment to specific minority grouphas been complicated and difficult question for constitutional law of the United States in recent years.

The American original constitution was lack of protecting equality under the law, but the Civil War Amendments emancipated the slaves and provided equal protection of law. However the actual conditions of racial discrimination in society which had continued since the colonial days could not cease to exist simply by constitutional amendments. The Supreme Court decision in Civil Rights Cases (1883) of holding Civil Rights Act (1875) to be unconstitutional had prevented federal statute from securing racial equality at privateowned facilities and the doctrine of "separate but equal" declared in Plessy v. Furguson (1896) established firmly racial segregation policy in the Southern States.

After the Second World War racial equality had progressed rapidly toward thoroughgoing realization of "color-blind" principle. The Supreme Court decision of famous Brown case (1954) and the enactment of Civil Rights Act (1964) seemed to provide perfect prohibition of discrimination because of race, color, creed and sex. Such "color-blind" policy set up equal starting point for every person who could make free competition alike in society.

But in cases where long-term discrimination has formed solid societal structure, even neutral standard as "color-blindness" was considered to result in re-producing discrimination. In order to achieve real equality through giving favorable measures to race suppressed for a long time, affirmative action policy has been proposed and taken by local ordinance, executive order, voluntary actions of business enterprise or university, etc. These measures seem to be contrary to "color blind" principle, because they provide reverse discrimination for majority race by giving preferential treatment to minority. 